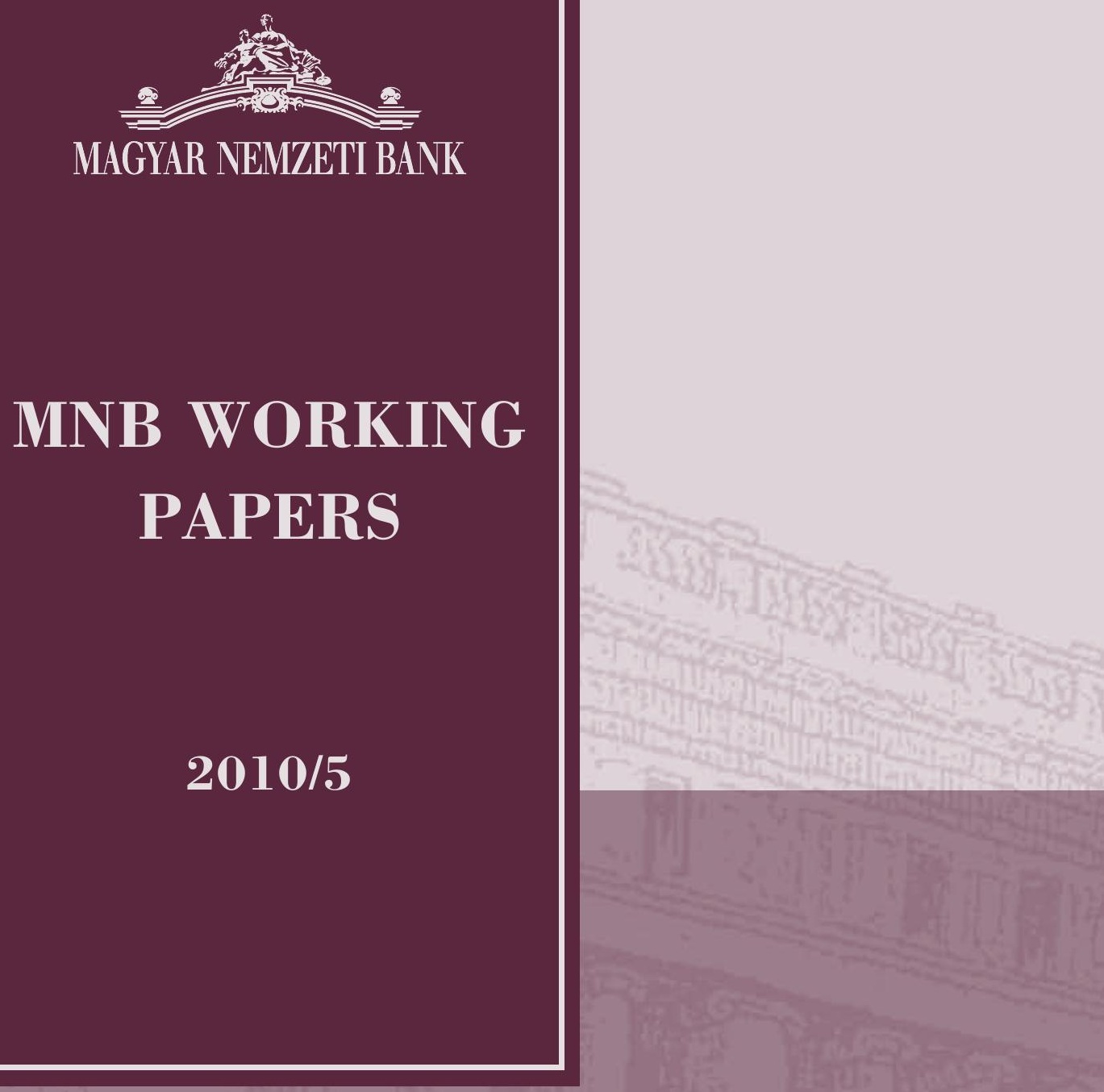

KATRIN RABITSCH

The role of financial market structure and the trade elasticity for monetary policy in open economies 



\section{The role of financial market structure and the trade elasticity for monetary policy in open economies}


The MNB Working Paper series includes studies that are aimed to be of interest to the academic community, as well as researchers in central banks and elsewhere. Starting from 9/2005, articles undergo a refereeing process, and their publication is supervised by an editorial board.

The purpose of publishing the Working Paper series is to stimulate comments and suggestions to the work prepared within the Magyar Nemzeti Bank. Citations should refer to a Magyar Nemzeti Bank Working Paper. The views expressed are those of the authors and do not necessarily reflect the official view of the Bank.

MNB Working Papers 2010/5

The role of financial market structure and the trade elasticity for monetary policy in open economies*

(A tôkepiaci szerkezet és a külkereskedelmi rugalmasságok hatása a nyitott gazdaságok monetáris politikájára)

Written by: Katrin Rabitsch**

Published by the Magyar Nemzeti Bank

Szabadság tér 8-9, H-1850 Budapest

http://www.mnb.hu

ISSN 15855600 (online)

* I thank Robert Kollmann, Margarita Rubio and Péter Benczúr for useful discussions, as well as participants at the MNB-CEPR Workshop 2009, the Vienna MacroeconomicsWorkshop 2009 and ASSET 2009.

** Department of Economics, Central European University and Research Department, Magyar Nemzeti Bank. E-mail: rabitschk@ceu.hu. 


\section{Contents}

$\begin{array}{lr}\text { Abstract } & 5\end{array}$

1 Introduction $\quad 6$

2 The Model $\quad 9$

Households $\quad 9$

Firms $\quad 12$

$\begin{array}{ll}\text { Resource Constraints and Aggregate Budget Constraints } & 13\end{array}$

Relative Prices and The Terms of Trade 14

3 Optimal Monetary Policy and International Risk Sharing 15

Definition of Equilibrium and Description of Constraints for Ramsey Problem 16

Definition of Ramsey problem under cooperation $\quad 18$

Definition of Ramsey problem under independently acting monetary authorities 18

4 Parameterization $\quad 20$

5 Results 21

$\begin{array}{ll}\text { Ramsey Steady State } & 21\end{array}$

$\begin{array}{ll}\text { Transmission under flexible versus sticky prices } & 21\end{array}$

The Role of Financial Market Structure and the Trade Elasticity for Stabilization 23

The Role of Risk Sharing for Gains from Policy Coordination and Gains over the Flexible Price Allocation $\quad 25$

Sensitivity Analysis $\quad 26$

6 Conclusion 27

$\begin{array}{lr}\text { References } & 28\end{array}$

$\begin{array}{ll}\text { Appendices } & 30\end{array}$

$\begin{array}{lr}\text { A Tables and Figures } & 30\end{array}$ 



\section{Abstract}

The degree of international risk sharing matters for how monetary policy should optimally be conducted in an open economy. This is because risk sharing affects the way in which monetary policy is affected by terms of trade considerations. In a standard two-country model with monopolistic competition and nominal rigidities I consider different assumptions on international financial markets - complete markets, financial autarky and a bond economy - and a large region for the crucial parameter of the trade elasticity. There are three main results: one, the prescription of (producer) price stability as the optimal policy is obtained only as a special case, while in general it is optimal to deviate from a strictly zero inflation rate. Two, while gains from international policy coordination are generally small, they become potentially substantial when international risk sharing is poor and wealth effects from shocks across countries are large. And, three, when international financial markets are incomplete, there are also (sometimes considerable) gains over the flexible price allocation achievable.

JEL: E52, E58, F42.

Keywords: monetary policy, risk sharing, price stability, policy coordination, financial market structure, trade elasticity.

\section{Összefoglalás}

A nemzetközi kockázatmegosztás mértéke fontos meghatározója a nyitott gazdaságok optimális monetáris politikájának. A kockázatmegosztás foka ugyanis hat arra, hogy a monetáris politika miként veszi figyelembe a cserearány-megfontolásokat. Egy sztenderd, kétországos modellben - monopolisztikus versenyt és ragadós árakat feltételezve - vizsgálom a nemzetközi tókepiacra vonatkozó különbözó lehetséges feltevéseket (teljes piacok, pénzügyi autarkia, illetve egyetlen kötvény esete), valamint a kereskedelmi rugalmasság paramétereink széles skáláját. A három fó eredmény a következó: (i) a termelói árindex stabilizálása csak egy speciális esetben optimális, általában célszerú eltérni a szigorú inflációs célkövetéstôl; (ii) a nemzetközi monetáris politikai kooperáció elónyei általában kicsik, kivéve alacsony nemzetközi kockázatmegosztás és erôs országok közötti jövedelemhatások esetén; (iii) ha a nemzetközi tókepiacok nem teljesek, a rugalmas árak melletti allokáció (néha jelentős mértékben) elmarad az optimálistól. 


\section{Introduction}

This paper presents a unifying framework to study the role of the degree of international risk sharing for optimal monetary policy in open economies. The main results are threefold: one, the prescription of (producer) price stability as the optimal policy is obtained only as a special case, while in general it is optimal to deviate from a strictly zero inflation rate. Two, while gains from international policy coordination are generally small, they become potentially substantial when international risk sharing is poor and wealth effects from shocks across countries are large. And, three, when international financial markets are incomplete, there are also (sometimes considerable) gains over the flexible price allocation achievable.

The framework used to address these issues is a relatively standard two-country imperfectly-competitive sticky-price model of the open economy. In such a setup, a number of imperfections characterize the economy that typically exert influence on the way monetary policy should optimally be conducted. As in the closed economy both countries are characterized by two internal distortions: because of monopolistic competition output is inefficiently low, and the economy's adjustment is subject to nominal rigidities in the form of quadratic price adjustment costs (assumed to be set in producer currency), which opens up an output gap relative to a world of flexible prices.

In addition, there is an external distortion which stems from a country's monopoly power on the relative price of its exports to imports, that is, on its terms of trade (TOT). ${ }^{1}$ The present paper shows that this international dimension of monetary policy, that is, the size and direction in which movements in the terms of trade enter into the consideration of monetary policy, depends crucially on the degree of international risk sharing.

The degree of risk sharing in turn, is determined by the structure of international financial markets assumed, as well as by the precise parameterization of the trade elasticity. For this purpose, I contrast three stylized assumptions on the international financial market structure - namely, complete markets (CM), financial autarky (FA) and an incomplete markets-bond economy (IM) - and consider a wide range of the trade elasticity. The latter is of importance as it governs the strength in which relative wealth is affected in response to country specific shocks. In the special case of a unitary elasticity (combined with log-utility) movements in the terms of trade provide full automatic risk sharing independent of the financial market structure assumed. ${ }^{2}$ An analysis of the role of the degree of risk sharing for optimal monetary policy can therefore only be addressed at values of the elasticity away from unity. In the previous literature there has been no consensus on the choice of the value of the trade elasticity - it has been all over the place. Therefore, I choose not to calibrate this parameter to a specific fixed value, but consider instead a large range for it, where domestic and foreign consumption goods are allowed to be either substitutes or complements. Moreover, I consider also very low elasticities in my analysis which have been shown to be necessary to reproduce - together with an incomplete financial market structure - the empirically observed low degrees of international risk sharing.

I study optimal monetary policy using a Ramsey approach and assuming that policymakers can commit. Gains from international policy coordination are computed by contrasting welfare achieved by a world social planner with the welfare achieved under uncoordinated (Nash) policy competition. On the methodological side, the present paper contributes to the literature by laying out a well defined Nash policy game in a dynamic economy in the framework of the Ramsey approach. In the following, I briefly discuss each of the three results found and position and contrast them with respect to the literature.

Turning to the first result in more detail, I find that for almost all cases of financial market assumptions and policy regimes considered the implications are that full stabilization is not the optimal monetary policy. By

\footnotetext{
${ }^{1}$ Throughout the paper, I refer to the terms of trade when talking about the influence of international prices on policy decisions. However, it should be noted that, equivalently, I could have referred to the real exchange rate as the relevant international price to consider (which in this model always moves proportionally to the terms of trade).

${ }^{2}$ In this case any income effects from shocks are offset by proportional movements in the international relative price (see, Cole \& Obstfeld (1991), Corsetti \& Pesenti (2001)).
} 
full stabilization I refer to a policy of achieving fully stable producer prices, such that the terms of trade behave exactly as in the world without nominal rigidities and the flexible price allocation is replicated (fully closing the output gap). Only in the case of complete markets under coordination and in the case of the unit-elasticity-'automatic perfect risk sharing' producer prices should be kept fully stabilized. ${ }^{3}$ Moreover, I document the precise patterns when it is optimal to fully stabilize, understabilize or overstabilize the economy. An interesting result is that the optimal policy is found to be exactly the opposite under CM and FA: when it is optimal for an independently acting policymaker to understabilize the economy under CM (full risk sharing), he finds it optimal to overstabilize the economy under FA (no risk sharing). ${ }^{4}$ In a recent contribution De Paoli (2009) documents a related result. She studies the role of financial market structure on optimal monetary policy in a small open economy in the form of comparing different targeting rules and finds that the welfare based ranking of these rules is in opposite order for the case of CM and FA. ${ }^{5}$

In particular, the above result can be understood as follows: let us consider a temporary domestic productivity increase as an example. Also, consider that domestic and foreign goods can easily be substituted in consumption. In response to the shock, an independently acting policymaker under CM finds it optimal to somewhat understabilize the economy. That is, while he lowers the interest rate to make output supply determined he does so not to the full degree to replicate the flexible price allocation and leaves a small output gap open. This also means that the resulting terms of trade depreciation is somewhat less pronounced and the policymaker enjoys a more favorable relative price compared to the flexible price world. By expanding output a little less he can reduce his labor effort at the prospect of keeping his utility from consumption as perfect international risk sharing holds and goods can easily be substituted. ${ }^{6}$ The situation is a different when countries are in financial autarky. In such a setup the policymaker finds it optimal to initiate an output increase that more that closes the output gap and that depreciates the terms of trade even more that under flexible prices, that is, he overstabilizes the economy. He does so because under FA output and consumption are very closely linked, so even though labor effort has to be increased, this is worth it as consumption can be raised as well.

Furthermore, even the coordinated policymaker under FA will follow this policy, in fact, will initiate an even larger terms of trade depreciation. This is because the policymaker under FA, coordinated or uncoordinated, has to consider an additional distortion in his design of monetary policy, the fact that the degree of risk sharing is too low and can be improved through a larger adjustment in international relative prices.

A second result is the dependence of welfare gains from policy coordination on the degree of risk sharing. The two-country setup allows for an explicit consideration of Nash versus coordinated optimal policies, which allows to also draw conclusions about the gains from policy cooperation. These are found increasing for elasticities of substitution away from unity and are typically an order of magnitude larger in the case of complementarity between domestic and foreign goods, particularly when risk sharing is low (FA and IM). In addition, I find that welfare gains from coordination are bigger under complete markets when goods are substitutes, but turn out to be bigger under financial autarky/ incomplete markets when goods are complements. This is due to the fact that the lack of risk sharing becomes even more important when, because of a low elasticity, international prices move strongly and wealth effects are large. Sutherland (2004) has previously studied the role of market structure for the gains of policy coordination in a simple static model, finding that welfare gains are rather small. In addition he only considers the case when goods are substitutes. On the one hand welfare gains are likely to be larger under more realistic, dynamic price rigidities ${ }^{7}$, on the other hand the case of low substitution elasticities is of particular interest as it is precisely the specification

\footnotetext{
${ }^{3}$ This is the 'isomorphism' and 'inward-looking' result of early contributions (see, e.g., Clarida et al. (2001), Galí \& Monacelli (2005), or Corsetti \& Pesenti (2001), Benigno \& Benigno (2003)).

${ }^{4}$ This finding is summarized graphically in Figure 2, which plots the impact responses (to a productivity shock) of producer price inflation as a function of the trade elasticity.

${ }^{5}$ The simple rules she considers are producer price inflation targeting, consumer price inflation targeting, and a fixed exchange rate regime.

${ }^{6}$ Under Nash policy competition, however, both countries behave in this fashion and the too low terms of trade volatility does no longer provide full risk sharing, leading to welfare losses.
} 
needed to reconcile the predictions of the theoretical model with the low degree of risk sharing observed in the data.

It is interesting to note, that even if policymakers act coordinately price stability is, in general, not found to be the optimal outcome. The reason for this finding is that the flexible price financial autarky economy (or bond economy) is not efficient as countries do not involve in any (too little) risk sharing. A policymaker that can, because of sticky prices, influence the terms of trade/ the real exchange rate finds it optimal to let it respond more closely to the way it would under complete financial markets, such that the equilibrium responses of the real exchange rate under the optimal policy is also doing some risk sharing. ${ }^{8}$ This desire to improve international risk sharing can be very strong, such that even in the Nash case, welfare gains over the flexible price allocation can be made, when financial markets are incomplete.

The rest of the paper is organized as follows. Section 2 describes the model, section 3 discusses the role of monetary policy in a world with various degrees of international risk sharing and sets up the relevant Ramsey problems. Section 2 discusses the model's parameterization. Section 5 discusses the results for optimal monetary policy depending on the degree of intratemporal elasticity and depending on the financial market structure, looking at the implications for the optimality of price stability and the gains from policy coordination. Section 6 concludes.

\footnotetext{
${ }^{7}$ Faia \& Monacelli (2004) also study the role of the terms of trade on optimal policy in a model with Rotemberg adjustment costs, but only consider the case of complete markets.

${ }^{8}$ A related point is made recently by Corsetti et al. (2009).
} 


\section{The Model}

The world economy consists of a Home country $(H)$ and a Foreign country $(F)$, each of which is specialized in the production of one type of tradable good. Households and firms are defined over a continuum of unit mass. Home and Foreign households are indexed by $j \in[0,1]$ and $j^{*} \epsilon[0,1]$ respectively. Each good is produced by firms in a number of varieties, indexed by $b$ in the Home country and by $f$ in the Foreign country. Each variety is an imperfect substitute to all other varieties and is produced under conditions of monopolistic competition. Firms face quadratic adjustment costs in their price setting decision and are assumed to set the price in the foreign market in their own currency (producer currency pricing). I abstract from modeling monetary frictions by considering a cashless economy. Unless necessary otherwise, in the following I only discuss the problem of Home agents, with an understanding that the problem for Foreign agents is symmetric - variables of Foreign agents are marked with an asterisk.

\section{HOUSEHOLDS}

\section{Preferences and Budget Constraint}

Household $j$ maximizes her lifetime expected utility:

$$
E_{0} \sum_{t=0}^{\infty} \beta^{t} U\left(C_{t}, L_{t}\right)=E_{0} \sum_{t=0}^{\infty} \beta^{t}\left\{\frac{C_{t}^{1-\sigma}(j)}{1-\sigma}-\frac{L_{t}^{1+\chi}(j)}{1+\chi}\right\},
$$

where $\beta$ is the discount factor, $C(j)$ is consumption and $L(j)$ is labor effort. Consumption $C(j)$ is a constant-elasticity-of-substitution (CES) basket over domestic and foreign goods:

$$
C_{t}(j)=\left[\gamma^{\frac{1}{\omega}} C_{H, t}^{\frac{\omega-1}{\omega}}(j)+(1-\gamma)^{\frac{1}{\omega}} C_{F, t}^{\frac{\omega-1}{\omega}}(j)\right]^{\frac{\omega}{\omega-1}}
$$

where $\omega$ denotes the trade elasticity, that is, the intratemporal elasticity of substitution between domestic and foreign goods, and where parameter $\gamma \geq \frac{1}{2}$ is the degree of home bias in consumption. For each household $j$ the consumption indices of Home varieties and Foreign varieties are defined as:

$$
C_{H, t}=\left[\int_{0}^{1} C_{t}(h, j)^{\frac{\theta-1}{\theta}} d h\right]^{\frac{\theta}{\theta-1}}, C_{F, t}=\left[\int_{0}^{1} C_{t}(f, j)^{\frac{\theta-1}{\theta}} d f\right]^{\frac{\theta}{\theta-1}},
$$

where $C_{t}(h, j)$ and $C_{t}(f, j)$ are respectively consumption of Home variety $h$ and Foreign variety $f$ by agent $j$ at time $t$.

Household $j$ maximizes equation (1) subject to the budget constraint. Each period household $j$ receives wage income, $W_{t} L_{t}(j)$, and dividends from the monopolistic firms they own, $\Pi_{t}(j)$, and has consumption expenditure $P_{t} C_{t}(j)$. The availability of any assets of domestic household $j$ depends on the assumptions of the structure of international financial markets. Throughout the paper, I consider three possible scenarios: complete markets (CM), financial autarky (FA) and an incomplete markets bond economy (IM). 
Under complete markets the household has access to a full set of state-contingent (Arrow-Debreu) securities. Let $Q\left(s_{t+1} \mid s_{t}\right)$ denote the price of one unit of Home currency delivered in period $t+1$ contingent on the state of nature at $t+1$ being $s_{t+1}$. With complete markets, $Q\left(s_{t+1} \mid s_{t}\right)$ is the same for all individuals. Let $B_{H, t}\left(j, s_{t+1}\right)$ denote the claim to $B_{H, t}$ units of Home currency at time $t+1$ in the state of nature $s_{t+1}$, that household $j$ buys at time $t$ and brings into time $t+1$. $Q^{*}\left(s_{t+1} \mid s_{t}\right)$ and $B_{F, t}\left(j, s_{t+1}\right)$ are defined similarly in terms of units of Foreign currency. $\varepsilon_{t}$ denotes the nominal exchange rate (units of Home currency per unit of Foreign currency). The budget constraint under complete markets is then given by:

$$
\begin{aligned}
& \sum_{s_{t+1}} Q\left(s_{t+1} \mid s_{t}\right) B_{H, t}\left(j, s_{t+1}\right)+\sum_{s^{t+1}} Q^{*}\left(s_{t+1} \mid s_{t}\right) \varepsilon_{t} B_{F, t}\left(j, s_{t+1}\right) \\
\leq & B_{H, t-1}\left(j, s_{t}\right)+\varepsilon_{t} B_{F, t-1}\left(j, s_{t}\right)+W_{t} L_{t}(j)+\Pi_{t}(j)-P_{t} C_{t}(j) .
\end{aligned}
$$

If the two economies are in financial autarky no assets can be traded internationally. Let $B_{H, t}(j)$ and $B_{F, t}(j)$ denote bonds denominated in either domestic and foreign currency. Under international financial autarky, the domestic currency bond, $B_{H, t}$, that can be traded only domestically. Equivalently, foreign agents can trade a foreign currency bond, $B_{F, t}^{*}$, but also only within their country. ${ }^{9}$ The budget constraint of domestic household $j$ under financial autarky then becomes:

$$
B_{H, t}(j)=B_{H, t-1}(j) R_{t-1}+W_{t} L_{t}(j)+\Pi_{t}(j)-P_{t} C_{t}(j)
$$

Finally, I consider the case of the incomplete markets-bond economy. I now assume that both countries can now engage in financial trade through one of the one-period nominal bonds. In particular, I assume that the foreign currency denominated bond, $B_{F, t}$, can be traded internationally (and net foreign wealth is initially zero). ${ }^{10}$ While this assumption introducing a small asymmetry into the otherwise symmetric setup, I do so because the domestic and foreign currency bond holdings are not separately identified. ${ }^{11}$ Following Schmitt-Grohé \& Uribe (2003) and Benigno (2001), to render the incomplete markets economy stationary, I assume that domestic agents face a quadratic adjustment cost when taking on an international asset position different from their long-run (zero) position. The budget constraint under the assumption of the incomplete markets-bond economy is:

$$
\begin{aligned}
& B_{H, t}(j)+\varepsilon_{t} B_{F, t-1}(j)+\frac{\phi}{2}\left(\frac{\varepsilon_{t} B_{F, t-1}(j)}{P_{t}}\right)^{2} P_{t} \\
\leq & B_{H, t-1}(j) R_{t-1}+\varepsilon_{t} B_{F, t-1}(j) R_{t-1}^{*}+W_{t} L_{t}(j)+\Pi_{t}(j)-P_{t} C_{t}(j) .
\end{aligned}
$$

\footnotetext{
${ }^{9}$ That is, the asset market clearing conditions under FA are $\int_{0}^{1} B_{H, t}(j) d j=0$ and $\int_{0}^{1} B_{F, t}^{*}\left(j^{*}\right) d j^{*}=0$.

${ }^{10}$ The nominal bonds are in zero net-supply worldwide, so that:$$
\int_{0}^{1} B_{H, t}(j) d j=0 \text { and } \int_{0}^{1} B_{F, t}(j) d j+\int_{0}^{1} B_{F, t}^{*}\left(j^{*}\right) d j^{*}=0
$$

${ }^{11}$ Moreover, it is important to note that the internationally traded asset is exogenously restricted to be the foreign currency bond only, for which a long-run zero position is simply assumed. In particular, this setup does not enter the recent literature on issues of portfolio choice and endogenous non-zero positions (see, e.g. Devereux \& Sutherland (2008) and Tille \& van Wincoop (2007)).
} 


\section{Households' Intratemporal Consumption Allocation}

Household $\mathrm{j}$ minimizes, each period, its consumption expenditure subject to obtaining a unit of the final consumption good. Denoting with $P_{t}$ the Lagrange multiplier to that problem ${ }^{12}$ gives the following optimal demand functions:

$$
\begin{gathered}
c_{t}(b, j)=\left(\frac{p_{t}(b)}{P_{H, t}}\right)^{-\theta} C_{H, t}(j)=\gamma\left(\frac{p_{t}(b)}{P_{H, t}}\right)^{-\theta}\left(\frac{P_{H, t}}{P_{t}}\right)^{-\omega} C_{t}(j), \\
c_{t}(f, j)=\left(\frac{p_{t}(f)}{P_{F, t}}\right)^{-\theta} C_{F, t}(j)=(1-\gamma)\left(\frac{p_{t}(f)}{P_{F, t}}\right)^{-\theta}\left(\frac{P_{F, t}}{P_{t}}\right)^{-\omega} C_{t}(j),
\end{gathered}
$$

For given Home-currency prices of varieties, $p_{t}(b)$ and $p_{t}(f)$ the utility-based CPI, $P_{t}$, is given by:

$$
P_{t}=\left[\gamma P_{H, t}^{1-\omega}+(1-\gamma) P_{F, t}^{1-\omega}\right]^{\frac{1}{1-\omega}}
$$

where

$$
P_{H, t}=\left[\int_{0}^{1} p_{t}(b)^{1-\theta} d b\right]^{\frac{1}{1-\theta}}, P_{F, t}=\left[\int_{0}^{1} p_{t}(f)^{1-\theta} d f\right]^{\frac{1}{1-\theta}} .
$$

\section{Households' Labor Supply and Intertemporal Allocation}

Denote with $\lambda_{t}(j)$ the Lagrange multiplier of the household's budget constraint. Household $j$ 's first order conditions with respect to $C_{t}(j)$ and $L_{t}(j)$ are identical for all possible financial market assumptions and are given by:

$$
P_{t} C_{t}^{\sigma}(j) L_{t}^{x}(j)=W_{t}
$$

Under complete financial market, the first order condition w.r.t. home and foreign Arrow-Debreu securities are given by:

$$
Q\left(s_{t+1} \mid s_{t}\right)=\beta E_{t}\left\{\left(\frac{C_{t+1}(j)}{C_{t}(j)}\right)^{-\sigma} \frac{P_{t}}{P_{t+1}}\right\}, Q^{*}\left(s_{t+1} \mid s_{t}\right)=\beta E_{t}\left\{\left(\frac{C_{t+1}(j)}{C_{t}(j)}\right)^{-\sigma} \frac{P_{t}}{P_{t+1}} \frac{\varepsilon_{t+1}}{\varepsilon_{t}}\right\},
$$

which can be combined to obtain the risk sharing equation:

$$
\frac{\varepsilon_{t} P_{t}^{*}}{P_{t}}=\left(\frac{C_{t}^{*}(j)}{C_{t}(j)}\right)^{-\sigma}
$$

\footnotetext{
${ }^{12}$ Formally,

$$
\min \int_{0}^{1} p_{t}(h) C_{t}(b, j) d h+\int_{0}^{1} p_{t}(f) C_{t}(f, j) d f-P_{t} C_{t}(j)
$$
}


Under financial autarky the domestic currency bond can only be held domestically such that

$$
1=\beta E_{t}\left\{R_{t}\left(\frac{C_{t+1}(j)}{C_{t}(j)}\right)^{-\sigma} \frac{P_{t}}{P_{t+1}}\right\} \text {. }
$$

Under the incomplete markets bond economy, the first order condition w.r.t. home and foreign bond are similarly given by:

$$
1=\beta E_{t}\left\{R_{t}\left(\frac{C_{t+1}(j)}{C_{t}(j)}\right)^{-\sigma} \frac{P_{t}}{P_{t+1}}\right\}, 1=\beta E_{t}\left\{R_{t}^{*}\left(\frac{C_{t+1}(j)}{C_{t}(j)}\right)^{-\sigma} \frac{P_{t}}{P_{t+1}} \frac{\varepsilon_{t+1}}{\varepsilon_{t}}\right\}
$$

The nominal interest rate $R_{t}$ and $R_{t}^{*}$ can be thought of as the underlying instruments of monetary policy in the two economies.

\section{FIRMS}

\section{Production and Price Setting}

The production function is assumed to be linear in labor:

$$
Y_{t}(b)=Z_{t} L_{t}(b)
$$

where $Z_{t}$ is the level of productivity, which is given by a country-specific $\operatorname{AR}(1)$ process with persistence parameter $\rho_{Z}$ and standard deviation $\sigma_{Z}$. Firms operate under conditions of monopolistic competition taking into account the downward-sloping demand for their product and set prices to maximize their profit. They are assumed to set the prices in the foreign market in their own currency, that is, I consider the scenario of producer currency pricing (PCP). Firms are small, in the sense that they ignore the impact of their pricing and production decisions on aggregate variables and price indices. When firms set their prices they have to take into consideration a quadratic adjustment cost, where parameter $\alpha$ measures the degree of price stickiness:

$$
\phi_{t}(b)=\frac{\alpha}{2}\left(\frac{p_{t}(b)}{p_{t-1}(b)}-1\right)^{2}
$$

The presence of Rotemberg adjustment costs makes the firms' price setting decision dynamic, which introduces richer and arguably more realistic equilibrium dynamic effects of monetary policy than in a setup where prices are set one period in advance. The richer description of price stickiness is also likely to be more appropriate for quantitative welfare analysis. I assume throughout that the law of one price holds, such that for each variety $h$ we have $\varepsilon_{t} p_{t}^{*}(b)=p_{t}(b)$. Each producer chooses its price $p_{t}(b)$ such as to maximize its total market value:

$$
E_{t}\left\{\sum_{t=0}^{\infty} \Omega_{0, t}\left[p_{t}(b)(1+\tau)-M C_{t}(b)\right]\left[\left(\frac{p_{t}(b)}{P_{H, t}}\right)^{-\theta}\left(C_{H, t}+C_{H, t}^{*}\right)\right]-\frac{\alpha}{2}\left(\frac{p_{t}(b)}{p_{t-1}(b)}-1\right)^{2} P_{H, t}\right\}
$$


where $M C_{t}$ is the marginal cost that minimizes labor input, which is equal to all firms, $M C_{t}(b)=M C_{t}=$ $W_{t} / Z_{t}, \Omega_{t, s}$ is the household's stochastic discount factor between time $t$ and $s$, and where $\tau$ stands for a production subsidy that can be used to offset the distortion from monopolistic competition.

\section{Firms' Optimality Conditions}

The firm's optimal price setting condition is derived as:

$$
\begin{aligned}
0= & {\left[\left(\frac{p_{t}(b)}{P_{H, t}}\right)^{-\theta}\left(C_{H, t}+C_{H, t}^{*}\right)\right]\left(\frac{p_{t}(b)}{P_{H, t}}\right)^{-1}\left[\theta \frac{M C_{t}(b)}{P_{H, t}}-(\theta-1)(1+\tau)\right]-} \\
& \alpha\left(\frac{p_{t}(b)}{p_{t-1}(b)}-1\right) \frac{P_{H, t}}{p_{t-1}(b)}+E_{t} \Omega_{t, t+1} \alpha\left(\frac{p_{t+1}(b)}{p_{t}(b)}-1\right) \frac{p_{t+1}(b) P_{H, t+1}}{p_{t}^{2}(b)} .
\end{aligned}
$$

Parameter $\alpha=0$ corresponds to the case of flexible prices, in which case the price is set as the a simple markup over current marginal costs.

I focus attention on a symmetric equilibrium where all domestic producers charge the same price, adopt the same technology and therefore choose the same demand for labor. This implies $p_{t}(b)=P_{H, t}, p_{t}^{*}(b)=P_{H, t}^{*}$, $L_{t}(b)=L_{t}, \Pi_{t}(j)=\Pi_{t}$.

\section{RESOURCE CONSTRAINTS AND AGGREGATE BUDGET CONSTRAINTS}

The resource constraint for each variety $h$ and each variety $f$ are given by:

$$
\begin{aligned}
& Y_{t}(b)=\int_{0}^{1} c_{t}(b, j) d j+\int_{0}^{1} c_{t}\left(b, j^{*}\right) d j^{*}+\int_{0}^{1} \phi_{t}(j) d j=C_{H, t}+C_{H, t}^{*}+\phi_{t}, \\
& Y_{t}^{*}(f)=\int_{0}^{1} c_{t}(f, j) d j+\int_{0}^{1} c_{t}\left(f, j^{*}\right) d j^{*}+\int_{0}^{1} \phi_{t}^{*}\left(j^{*}\right) d j^{*}=C_{F, t}+C_{F, t}^{*}+\phi_{t}^{*} .
\end{aligned}
$$

Symmetry across all households $j$ gives $C_{t}(j)=C_{t}, L_{t}(j)=L_{t}, \lambda_{t}(j)=\lambda_{t}$, and implies that conditions (7)-(8), (11)-(13), (14) and (15) must also hold for aggregate variables and indices $j$ can be dropped.

In addition, using equilibrium in the asset markets the aggregate budget constraint under the case of financial autarky, having imposed clearing conditions, can be expressed as:

$$
0=W_{t} L_{t}+\Pi_{t}-P_{t} C_{t} .
$$

In the incomplete markets bond economy, after imposing asset market clearing conditions the budget constraint becomes:

$$
\varepsilon_{t} B_{F, t}+\frac{\phi}{2}\left(\frac{\varepsilon_{t} B_{F, t-1}}{P_{t}}\right)^{2} P_{t}=B_{F, t-1} R_{t-1}^{*}+W_{t} L_{t}+\Pi_{t}-P_{t} C_{t} .
$$




\section{RELATIVE PRICES AND THE TERMS OF TRADE}

The terms of trade is defined as the price of imports to exports, $\frac{P_{F, t}}{\varepsilon_{t} P_{H, t}^{*}}$, which given the law of one price can be written as:

$$
\operatorname{TOT}_{t}=\frac{P_{F, t}}{P_{H, t}}
$$

Using the optimal consumer price level resulting from the intratemporal allocation problem, it is possible to express all relative prices as a function of the terms of trade only. In particular, the real exchange rate, which is the price of a foreign consumption bundle relative to domestic consumption bundle, that is, $R E R_{t}=$ $\left(\varepsilon_{t} P_{t}^{*}\right) / P_{t}$, is related to the terms of trade by:

$$
R E R_{t}=f^{R E R}\left(T O T_{t}\right)=\frac{\left[\gamma^{*}+\left(1-\gamma^{*}\right) T O T_{t}^{1-\omega}\right]^{\frac{1}{1-\omega}}}{\left[\gamma+(1-\gamma) T O T_{t}^{1-\omega}\right]^{\frac{1}{1-\omega}}} .
$$

The PPI-to-CPI ratios are defined as $p_{H, t} \equiv P_{H, t} / P_{t}$ and $p_{F, t}^{*} \equiv P_{F, t}^{*} / P_{t}^{*}$ and can also be written as functions of the terms of trade only:

$$
\begin{aligned}
p_{H, t} & =f^{p_{H}}\left(T_{O} O T_{t}\right)=\left[\gamma+(1-\gamma) T O T_{t}^{1-\omega}\right]^{-\frac{1}{1-\omega}} \\
p_{F, t}^{*} & =f^{p_{F}^{*}}\left(T O T_{t}\right)=\left[\gamma^{*} T O T_{t}^{\omega-1}+\left(1-\gamma^{*}\right)\right]^{-\frac{1}{1-\omega}}
\end{aligned}
$$




\section{Optimal Monetary Policy and International Risk Sharing}

Having completed the description of the model economy, I now turn to studying the optimal monetary policy in this two-country imperfectly competitive sticky price economy. The particular focus will lie on how the degree of international risk sharing affects the scope and goals of monetary policy and if the predictions for optimal monetary policy in this otherwise standard model are altered.

For this reason, it is useful to first reflect on the distortions that characterize the economy. As in the closed economy both countries are characterized by two internal distortions: price stickiness and monopolistic competition. The latter produces an inefficient level of output. The other internal distortion, price stickiness, prevents efficient adjustment to the disturbances that affect the economy and opens up a gap of output relative to the flexible price allocation. The consensus result of the literature is that a procyclical policy can remove the sticky-price distortion by making production supply-determined and can restore the flex-price equilibrium if desirable.

In addition to the two internal distortions, there is an external distortion which stems from countries' monopoly power on the international relative price, that is, on their terms of trade. The strength and direction in which terms of trade considerations enter monetary policy crucially depends on the amount of international risk sharing, which in turn depends on a) the assumptions on asset markets and b) the degree of substitutability between domestic and foreign goods. In order to study this external dimension of monetary policy, that is, the role of the monopoly power over the terms of trade for monetary policy I follow Sutherland (2004) and Benigno (2009) in considering a setup in which the presence of a production subsidy fully offsets the distortion from monopolistic competition. This allows me to isolate the influence of terms of trade considerations for the conduct of monetary policy. ${ }^{13}$

In the setup of complete financial markets, a policymaker therefore only faces the distortion of sticky prices and the fact that he has monopoly power over the terms of trade. While a coordinated policymaker fully takes into account the effect of movements in the terms of trade on world welfare, a non-coordinated policymaker will seek to use his monopoly power to maximize his own country's welfare, ignoring the effect of such a strategy on the other country.

Under incomplete markets (FA or IM) policymakers also face a situation in which the degree of international risk sharing is too low. Therefore a coordinated policymaker will aim at using his instrument, on the one hand, as before, to make demand supply-determined, on the other hand, to try to improve international risk sharing. A non-coordinated policymaker's terms of trade considerations are now influenced by both his desire to tilt the terms of trade in his favor, but also by improving risk sharing properties to some degree.

For all financial market assumptions considered, the single most important parameter that influences both size and direction of terms of trade considerations is the intratemporal elasticity of substitution between domestic and foreign goods, the trade elasticity. It determines the strength of expenditure switching effects of the exchange rate/ terms of trade and therefore the impact of monetary policy on goods demand in different countries. It also influences the degree to which countries are subject to asymmetric income shocks. If the elasticity is close to unity then relative price changes are largely offset by changes in output volumes and the terms of trade provide strong automatic risk sharing (see Cole \& Obstfeld (1991)).

I assume throughout that policymakers can credibly commit in the sense that they can choose the entire future (state-contingent) evolution of the control variables, once and for all, at date zero. The assumption of commitment is important, as private sector expectations about the evolution of prices affect the forward

${ }^{13}$ Sensitivity analysis will be conducted in section 5 and will allow for a relaxation of this simplifying assumption. 
looking terms in the dynamic pricing equations. I study these issues by employing a Ramsey type approach, following closely the steps outlined in Schmitt-Grohé \& Uribe (2009) to obtain the steady state and dynamics implied by the Ramsey equilibrium. ${ }^{14}$ In this setup the optimal monetary policy entails a Ramsey planner which maximizes a social objective function subject to the private sector's constraints. ${ }^{15}$ I compare optimal commitment policy under Nash competition and under cooperation, and compute welfare gains from coordination from a second order approximation to the Ramsey equilibrium equations.

\section{DEFINITION OF EQUILIBRIUM AND DESCRIPTION OF CONSTRAINTS FOR RAMSEY PROBLEM}

An equilibrium requires that households and firms behave optimally, as described by the above optimality conditions. Specifically, given exogenous processes for $Z_{t}$ and $Z_{t}^{*}$, a policy for $R_{t}$ and $R_{t}^{*}$ and given initial conditions, a symmetric world competitive equilibrium is a set of prices and quantities that

- satisfy the Home and Foreign consumers' optimality conditions, equations (7)-(11), and their foreign counterparts, together with:

- the risk sharing equation (13) under complete financial markets

- equation (14) and the budget constraint, equation (23), under the incomplete markets-bond economy

- the budget constraint, equation (22), under the financial autarky

- maximize firms profits, meaning that prices are set according to (19) and similarly in the foreign economy,

- satisfy the market clearing conditions for each asset and each good, in all the markets where it is traded, and

- satisfy the resource constraints.

It is possible to reduce the system of equilibrium conditions to a system of equations in $C_{t}, C_{t}^{*}, L_{t}, L_{t}^{*}, \pi_{H, t}$, $\pi_{F, t}^{*}$, and $T O T_{t}$ only - given exogenous processes for $Z_{t}$ and $Z_{t}^{*}$, and for a policy for $R_{t}$ and $R_{t}^{*}$. In particular, plugging in for the demand functions (7) and (8) together with their foreign counterparts, making use of the fact that $\pi_{t}=\frac{p_{H, t-1}}{p_{H, t}} \pi_{H, t}, \pi_{t}^{*}=\frac{p_{F, t-1}^{*}}{p_{F, t}^{*}} \pi_{F, t}^{*}$, and by using the functional relationships between the real exchange rate and the terms of trade (equation (25)) and the PPI-to-CPI ratio and the terms of trade (equation (26)), it is possible to write the equilibrium as being described by equations (27)-(33) below. Equations (27)-(28) are the two Euler equations, equations (29)-(30) the two price setting equations, equations (31)-(32) the two resource constraints, and equations (33a), (33b) or (33c) are the relevant optimality conditions that hold under complete markets, financial autarky or the bond economy respectively.

$$
1=\beta E_{t}\left\{R_{t}\left(\frac{C_{t+1}}{C_{t}}\right)^{-\sigma} \frac{1}{\pi_{t+1}}\right\},
$$

\footnotetext{
${ }^{14}$ This builds on previous work on the study of optimal policy in dynamic economies, see e.g., (Ramsey (1927)), Atkinson \& Stiglitz (1976), Lucas \& Stokey (1983), Chari et al. (1991).

${ }^{15}$ While most studies of optimal monetary policy in the recent literature build on a linear-quadratic approximation approach in the spirit of Rotemberg \& Woodford (1997), Woodford (2003), and Benigno \& Woodford (2005), recently, the Ramsey type approach has been employed in an increasing number of dynamic equilibrium models with monopolistic competition and nominal rigidities. Examples include, among others, Khan et al. (2003), Schmitt-Grohé \& Uribe (2005, 2007), and Faia \& Monacelli (2004).
} 


$$
\begin{gathered}
1=\beta E_{t}\left\{R_{t}^{*}\left(\frac{C_{t+1}^{*}}{C_{t}^{*}}\right)^{-\sigma} \frac{1}{\pi_{t+1}^{*}}\right\}, \\
\alpha\left(\pi_{H, t}-1\right) \pi_{H, t}=\left(p_{H, t}\right)^{-\omega}\left[C_{t}+R E R_{t}^{\omega} C_{t}^{*}\right]\left[\theta\left(\frac{L_{t}^{*} C_{t}^{\sigma}}{Z_{t} p_{H, t}}\right)-(\theta-1)(1+\tau)\right] \\
+E_{t}\left(\frac{C_{t+1}}{C_{t}}\right)^{-\sigma} \frac{p_{H, t+1}}{p_{H, t}} \alpha\left(\pi_{H, t+1}-1\right) \pi_{H, t+1}, \\
\alpha\left(\pi_{F, t}^{*}-1\right) \pi_{F, t}^{*}=\left(p_{F, t}^{*}\right)^{-\omega}\left[R E R_{t}^{-\omega} C_{t}+C_{t}^{*}\right]\left[\theta\left(\frac{L_{t}^{* x} C_{t}^{* \sigma}}{Z_{t}^{*} p_{F, t}^{*}}\right)-(\theta-1)(1+\tau)\right] \\
+E_{t}\left(\frac{C_{t+1}}{C_{t}}\right)^{-\sigma} \frac{p_{F, t+1}^{*} \alpha\left(\pi_{F, t+1}^{*}-1\right) \pi_{F, t+1}^{*},}{p_{F, t}^{*}} \\
Z_{t} L_{t}=\left(p_{H, t}\right)^{-\omega}\left[C_{t}+R E R_{t}^{\omega} C_{t}^{*}\right], \\
Z_{t}^{*} L_{t}^{*}=\left(p_{F, t}^{*}\right)^{-\omega}\left[R E R_{t}^{-\omega} C_{t}+C_{t}^{*}\right],
\end{gathered}
$$

under complete markets:

$$
R E R_{t}=\left(\frac{C_{t}^{*}}{C_{t}}\right)^{-\sigma}
$$

under financial autarky:

$$
p_{H, t}\left(Z_{t} L_{t}\right)-\phi_{t}=C_{t},
$$

under incomplete markets, bond economy ${ }^{16}$ :

$$
\begin{aligned}
\left(1+\psi R E R_{t} b_{F, t}\right) & =\beta E_{t}\left\{R_{t}^{*}\left(\frac{C_{t+1}}{C_{t}}\right)^{-\sigma} \frac{1}{\pi_{t+1}^{*}} \frac{R E R_{t+1}}{R E R_{t}}\right\}, \\
R E R_{t} b_{F, t}+\frac{\phi}{2}\left(R E R_{t} b_{F, t}\right)^{2} & =R E R_{t} b_{F t-1} \frac{R_{t-1}^{*}}{\pi_{t}^{*}}+p_{H, t}\left(Z_{t} L_{t}\right)-C_{t}-\phi_{t} .
\end{aligned}
$$

\footnotetext{
${ }^{16}$ The budget constraint is also expressed in real terms, where $b_{F, t}=B_{F, t} / P_{t}^{*}$.
} 


\section{DEFINITION OF RAMSEY PROBLEM UNDER COOPERATION}

To derive the Ramsey optimal monetary policy under cooperation, I set up the problem of a world social planner that aims at maximizing the country-size weighted average measure of welfare, which are given by the lifetime expected utilities:

$$
W_{t}^{\text {average }}=\frac{1}{2} E_{0} \sum_{t=0}^{\infty} \beta^{t}\left\{U\left(C_{t}, L_{t}\right)+U\left(C_{t}^{*}, L_{t}^{*}\right)\right\}
$$

Let $i=C M, F A, I M$ denote the three assumptions on financial market structure. Define the vector of Ramsey constraints as $R C_{t}^{i}$, by vertically stacking equilibrium equations (27)-(33). Also, let superscript ${ }^{\prime} C^{\prime}$ refer to the case of policymakers acting under coordination. I define the vector of Lagrange multipliers at time $t$ attached to constraints (27)-(33) by $\Lambda_{t}^{i, C}$, where $\Lambda_{t}^{i, C}=\left[\lambda_{H 1, t}^{i, C}, \lambda_{F 1, t}^{i, C}, \lambda_{H 2, t}^{i, C}, \lambda_{F 2, t}^{i, C}, \lambda_{H 3, t}^{i, C}, \lambda_{F 3, t}^{i, C}, \lambda_{4, t}^{i, C}\right] .{ }^{17}$ In this dynamic economy it is not possible to solve in closed form the decentralized economy as a function of policy instruments only. Different from Chari \& Kehoe (1999) the Ramsey problem is therefore set up by carrying the model's equilibrium conditions as constraints, that implicitly define the economy's allocation as a functions of the instruments, $R_{t}$ and $R_{t}^{*}$. In particular, following Schmitt-Grohé \& Uribe (2009), I find the portion of the Ramsey problem that is relevant for the purpose of computing the optimal policy from the timeless perspective by:

$$
\begin{aligned}
L^{C M C}= & \ldots+\frac{1}{2}\left[U\left(C_{t}, L_{t}\right)+U\left(C_{t}^{*}, L_{t}^{*}\right)\right]+\frac{1}{2} \beta E_{t}\left[U\left(C_{t+1}, L_{t+1}\right)+U\left(C_{t+1}^{*}, L_{t+1}^{*}\right)\right] \\
& +\frac{1}{\beta} \Lambda_{t-1}^{i, C} R C_{t-1}^{i}+\Lambda_{t}^{i, C} E_{t} R C_{t}^{i}+\beta E_{t} \Lambda_{t+1}^{i, C} R C_{t+1}^{i} .
\end{aligned}
$$

The optimal policy can then be described by the first order conditions of the Lagrangian with respect to $\Lambda_{t}^{i, C}$, and $C_{t}, C_{t}^{*}, L_{t}, L_{t}^{*}, \pi_{H, t}, \pi_{F, t}^{*}, T O T_{t}, R_{t}, R_{t}^{*}$.

\section{DEFINITION OF RAMSEY PROBLEM UNDER INDEPENDENTLY ACTING MONETARY AUTHORITIES}

If monetary authorities act uncoordinated, the home and foreign policymaker each maximize their respective national welfare, taking as given the other country's choice of policy, that is, either interest rate $R_{t}$ or $R_{t}^{*}$. In particular, the objective of the domestic and the foreign policymaker are given, respectively, by:

$$
\begin{aligned}
W_{t} & =E_{0} \sum_{t=0}^{\infty} \beta^{t}\left\{U\left(C_{t}, L_{t}\right)\right\}, \\
W_{t}^{*} & =E_{0} \sum_{t=0}^{\infty} \beta^{t}\left\{U\left(C_{t}^{*}, L_{t}^{*}\right)\right\} .
\end{aligned}
$$

A Nash equilibrium is defined as a situation in which both countries choose the level of consumption, labor and inflation, and the policy instrument to maximize their objective, but where the other country's consumption, labor and inflation depend themselves on the policy choice of the first (not simply taken as given).

\footnotetext{
${ }^{17}$ As the incomplete markets-bond economy the the vector of constraints includes two financial market specific equations and the size of Lagrange multipliers is accordingly enlarged.
} 
As such, the home Ramsey policymaker should take as constraints its own Euler equation, pricing equation and resource constraint and financial market equilibrium condition as the relevant Ramsey constraints, plus the foreign consumption, labor and inflation choices as a function of its choice of the policy instrument. But these are nothing else than implicit functions defined by the foreign Euler equation, pricing equation and resource constraint. Therefore, each policymaker takes the entire competitive equilibrium conditions, given by equations (27)-(32) and the relevant financial market equilibrium equation, equation (33a), (33b) or (33c), as constraints to the Ramsey policy problem. ${ }^{18}$

The vector of constraints for the domestic and the foreign authority is given, as under coordination, by $R C_{t}^{i}$ for $i=C M, F A, I M$. Also, define the sequence of the vector of Lagrange multipliers attached to constraints in $R C_{t}^{i}$ by $\Lambda_{t}^{i, N}=\left[\lambda_{H 1, t}^{i, N}, \lambda_{F 1, t}^{i, N}, \lambda_{H 2, t}^{i, N}, \lambda_{F 2, t}^{i, N}, \lambda_{H 3, t}^{i, N}, \lambda_{F 3, t}^{i, N}, \lambda_{4, t}^{i, N}\right]$ and $\Lambda_{t}^{* i, N}=\left[\lambda_{H 1, t}^{* i, N}, \lambda_{F 1, t}^{* i, N}, \lambda_{H 2, t}^{* i, N}, \lambda_{F 2, t}^{* i, N}, \lambda_{H 3, t}^{* i, N}\right.$, $\left.\lambda_{F 3, t}^{* i, N}, \lambda_{4, t}^{* i, N}\right]$, where superscript ${ }^{\prime} N^{\prime}$ refers to the scenario of complete markets and Nash policymakers. The relevant portions of the Ramsey problems of the Lagrangians of the optimal policy problem of the domestic and foreign policymaker are then given by:

$$
\begin{aligned}
L^{i, N}= & \ldots+U\left(C_{t}, L_{t}\right)+\beta E_{t} U\left(C_{t+1}, L_{t+1}\right) \\
& +\frac{1}{\beta} \Lambda_{t-1}^{i, N} R C_{t-1}^{i}+\Lambda_{t}^{i, N} E_{t} R C_{t}^{i}+\beta E_{t} \Lambda_{t+1}^{i, N} R C_{t+1}^{i}, \\
L^{* i, N}= & \ldots+U\left(C_{t}^{*}, L_{t}^{*}\right)+\beta E_{t} U\left(C_{t+1}^{*}, L_{t+1}^{*}\right) \\
& +\frac{1}{\beta} \Lambda_{t-1}^{* i, N} R C_{t-1}^{i}+\Lambda_{t}^{* i, N} E_{t} R C_{t}^{i}+\beta E_{t} \Lambda_{t+1}^{* i, N} R C_{t+1}^{i} .
\end{aligned}
$$

Taking derivatives of $L^{i, N}$ with respect to $\Lambda_{t}^{i, N}$, and $C_{t}, C_{t}^{*}, L_{t}, L_{t}^{*}, \pi_{H, t}, \pi_{F, t}^{*}, T O T_{t}$, and $R_{t}$ summarizes the optimal policy of the domestic monetary authority, conditional on a foreign policy $R_{t}^{*}$. Equivalently, the derivatives of $L^{* i, N}$ with respect to $\Lambda_{t}^{* i, N}$, and $C_{t}, C_{t}^{*}, L_{t}, L_{t}^{*}, \pi_{H, t}, \pi_{F, t}^{*}, T O T_{t}$, and $R_{t}^{*}$ summarize the optimal policy of the foreign monetary authority, conditional on domestic policy $R_{t}$. The full Nash equilibrium can then be obtained by combining the Ramsey optimality conditions of the domestic and foreign policymakers (it should be noted, that the first order condition w.r.t. the vector of Lagrange multipliers of both policymakers are identical, that is, they simply return the equations of the competitive equilibrium) ${ }^{19}$

\footnotetext{
${ }^{18}$ This is in contrast to Faia \& Monacelli (2004) and Liu \& Pappa (2008) who take the each country's own optimality conditions as a constraints in the uncoordinated Ramsey problem (taking as given the other country's consumption, labor and inflation choices in addition to the policy instrument).

${ }^{19}$ As in the case of coordination, the incomplete markets bond economy consists of two financial market related equilibrium conditions, and the vectors of Lagrange multipliers are correspondingly expanded to $\Lambda_{t}^{I M N}=\left[\lambda_{H 1, t}^{I M N}, \lambda_{F 1, t}^{I M N}, \lambda_{H 2, t}^{I M N}, \lambda_{F 2, t}^{I M N}, \lambda_{H 3, t}^{I M N}, \lambda_{F 3, t}^{I M N}, \lambda_{4, t}^{I M N}, \lambda_{5, t}^{I M N}\right]$ and $\Lambda_{t}^{* I M N}=\left[\lambda_{H 1, t}^{* I M N}\right.$, $\left.\lambda_{F 1, t}^{* I M N}, \lambda_{H 2, t}^{* I M N}, \lambda_{F 2, t}^{* I M N}, \lambda_{H 3, t}^{* I M N}, \lambda_{F 3, t}^{* I M N}, \lambda_{4, t}^{* I M N}, \lambda_{5, t}^{* I M N}\right]$
} 


\section{Parameterization}

The baseline parameterization of the model is summarized in Table 1, in section 5 I consider some parameter variations. The discount factor $\beta$ is taken to be 0.99 , implying an annual interest rate of about 4 percent. Parameter $\theta$ is taken to be 6 , which implies a markup over marginal cost of about 20 percent. Parameter $\gamma\left(\gamma^{*}\right)$, which is the weight on domestic good in the domestic (foreign) consumption basket, is set to 0.75 (0.25) in the baseline case, implying that there is positive home bias. The value of the parameter of the quadratic adjustment cost in price setting, $\alpha$, is 60, which corresponds, together with the chosen value for $\theta$, to a parameter of about 0.75 in a Calvo style price setting or a price stickiness of about four quarters, based on the slope coefficient in the linearized pricing equations (see, e.g. Faia \& Monacelli (2008)). The degree of risk aversion, $\sigma$, is considered to be 1 in the baseline parameterization (which implies log utility in consumption). The inverse Frisch elasticity of labor supply, $x$, is equal to 2 , a value that lies well in the region used in the literature (e.g. Rotemberg \& Woodford (1997) suggest a value of 0.47, while micro data on (low) estimated Frisch elasticities suggest values as high as 5, which is chosen e.g. by Benigno (2009). The production subsidy parameter is set such that it offsets the monopolistic competition distortion, that is, $\tau$, is set equal to $1 /(\theta-1)$. As for the exogenous processes, I consider, in line with most of the international business cycle literature, a rather persistent technology shock with autocorrelation coefficient of $\rho^{*}=0.95$, and with standard deviation of the shock of $\sigma_{\varepsilon}, \sigma_{\varepsilon}^{*}=0.01$.

Finally, I consider a wide range for the value of the trade elasticity, ranging from goods being very complementary in consumption to goods being very substitutable. As I show, the value of the trade elasticity is a most crucial parameter in determining the influence of terms of trade considerations in shaping optimal monetary policy in an open economy. Also, there is no consensus on the choice for this parameter in the literature. In the trade literature, Lai \& Trefler (2002) estimate, for individual goods, trade elasticities of around 5 and higher. In the business cycle literature, the trade elasticity is typically taken to be lower. Backus et al. (1995) use elasticities between 0 and 5, Chari et al. (2002) assume a value of 1.5. A number of recent contributions have also emphasized the role of a low elasticity of intratemporal substitution (well in the complementarity region) together with an incomplete financial markets structure in the transmission of productivity shocks across countries, in particular in addressing stylized facts on international relative prices and the low degrees of international risk sharing observed in the data (see e.g., Heathcote \& Perri (2002), Corsetti et al. (2008), Thoenissen (2008), Enders \& Mueller (2009)). In particular, as Corsetti et al. (2008) show, the volatility of the terms of trade or the exchange rate becomes particularly high around a threshold of the trade elasticity that is related to the degree of home bias and lies at $1-\frac{1}{2 \gamma} .20$ For values of the trade elasticity close to that threshold the terms of trade under incomplete financial markets behave markedly different than under complete financial markets, leading to low degrees of risk sharing. Thus, an analysis of the effects of varying degrees of international risk sharing for optimal monetary policy should also specifically consider this region of low elasticities.

\footnotetext{
${ }^{20}$ Moreover, they show that for values of the trade elasticity below the threshold, the TOT appreciate in response to a home productivity increase which leads to a decrease in foreign consumption (which is in line with empirical response for the case of the US), whereas above the threshold the TOT depreciate and transmission to the other country is positive.
} 


\section{Results}

\section{RAMSEY STEADY STATE}

Section 2 has shown that the Ramsey equilibrium under the various financial market assumption and under coordination or Nash is obtained as the system of equations of first order conditions derived from the appropriate Ramsey problem. To determine the long-run inflation rate associated to the optimal policy problems above, one needs to solve the steady-state versions of the set of efficiency conditions. In all economies and regimes considered, the steady state (gross) inflation rate associated to the optimal policy problem is found to be equal to 1 , as can be seen from the first order condition with respect to $\pi_{H, t}$ and $\pi_{F, t}^{*}{ }^{21}$ Hence the Ramsey planner would like to generate an average (net) inflation rate of zero. The intuition for this result is simple. Under commitment, the planner cannot systematically affect the economy through monetary surprises and, thus, there is not a terms of trade externality as the one discussed in Corsetti \& Pesenti (2001) and Clarida et al. (2001). That is, the planner cannot on average resort to movements in inflation to alter the relative purchasing power of its residents. The planner therefore aims at choosing a long-run inflation rate that minimizes the cost of adjusting prices, which is summarized by the quadratic term. The openness dimension of the desire of adjusting the terms of trade can, therefore, drive the planner's behavior only in the presence of equilibrium fluctuations (as induced by country-specific shocks) around the same long-run steady state.

\section{TRANSMISSION UNDER FLEXIBLE VERSUS STICKY PRICES}

To facilitate the analysis of optimal monetary policy, I first examine a useful benchmark in which price adjustment is flexible, and then describe the dynamics under sticky prices. In this flexible price environment, there is no scope for monetary policy. I study this case in detail however, as the flexible price allocation is a natural reference case, and I will, in the following, often relate the optimal monetary policy to such a benchmark. Under flexible prices a productivity increase in the domestic economy leads to a higher abundance of domestic goods. This translates into a decrease in the price of domestic goods resulting in a depreciation of the domestic terms of trade, making domestic goods relatively cheaper and channeling world demand towards domestic goods. Figure 1 shows the responses to the domestic productivity shock of major variables for the three financial market structures (CM, FA, and IM-Bond) and for the case where goods are either substitutes $(\omega=3)$, complements $(\omega=0.7)$ or are unit-elastic $(\omega=1)$.

Let's focus first on the case of goods being substitutes and consider the scenario of complete financial markets. The increase in domestic productivity leads to a domestic consumption increase, labor effort rises as the home economy gets more productive and the terms of trade deteriorate. Enjoying a more favorable price and because it is easy to substitute to the now more abundant domestic good the foreign country also benefits

\footnotetext{
${ }^{21}$ This is the case even if the monopolistic distortion were not offset. In particular, the Ramsey first order condition w.r.t. $\pi_{H, t}$ is given by:$$
0=\xi_{2 H, t}^{i} \alpha\left(\pi_{H, t}-1\right)+\left[\begin{array}{c}
\left(\xi_{3 H, t}^{i}-\xi_{3 H, t-1}^{i}\left(\frac{C_{t}}{C_{t-1}}\right)^{-\sigma} \frac{f^{p_{H}}\left(\mathrm{TOT}_{t}\right)}{f^{p_{H}}\left(T O T_{t-1}\right)}\right) \\
{\left[\alpha\left(2 \pi_{H, t}-1\right)\right]-\xi_{1 H, t-1}^{i} R_{t-1}\left(\frac{C_{t}}{C_{t-1}}\right)^{-\sigma} \frac{f^{p_{H}}\left(T O T_{t}\right)}{f^{p_{H}}\left(T O T_{t-1}\right)}}
\end{array}\right]
$$$$
\text { which, at steady state (as } \left.\xi_{3 H, t}^{i}=\xi_{3 H, t-1}^{i}=\xi_{3 H}^{i} \text { and } \xi_{1 H, t}^{i}=\xi_{1 H}^{i}=0\right) \text { implies }
$$$$
0=\xi_{2 H}^{i} \alpha\left(\pi_{H}-1\right)
$$ 
from the domestic productivity shock. In particular, under complete markets, the terms of trade depreciate just enough to equalize the marginal utility benefit from the productivity shock in both countries, as dictated by the risk sharing equation. In the other extreme case of financial autarky, the response of the terms of trade is somewhat less pronounced. While the terms of trade still depreciates as an equilibrium response to the now more abundant domestic goods, it does so to a much lesser extent than in the case where marginal utility had to be equalized. As no state-contingent assets have been traded promising the Foreign country part of the benefits, Home labor effort does not increase, the expansion in domestic output is therefore lower than in the complete markets case, and the fall in the price of domestic goods relative to foreign goods (that is, the terms of trade deterioration) in turn less pronounced. When goods are substitutes the TOT and labor move too little under incomplete financial markets relative to CM.

The transmission of the productivity shock is somewhat different when goods are complements. Generally speaking, a lower elasticity of substitution implies that for any given change in quantities, higher movements in the price are necessary to bring about these movements in quantities. That is, under all financial market structures, the terms of trade responses are now much stronger than in the case where goods are substitutes. In addition, the TOT now depreciates more in the case of incomplete financial markets than under complete markets. Because home and foreign goods are complementary in utility from consumption, the (productivity-induced) higher abundance of domestic goods also leads to a higher demand for foreign goods. If markets are complete the foreign country is therefore bound to expand its output by increasing its labor effort which tends to take some of the pressure of the terms of trade increasing. Under financial autarky such an increase in foreign output is absent, as a result the increased demand for the foreign goods without a counterbalancing increase in supply for it leads to a deterioration of the terms of trade that is even stronger. The lower the trade elasticity, the stronger is the terms of trade depreciation, and the foreign country increasingly benefits from the domestic productivity increase. Summarizing, now, when goods are complements the TOT move too much under incomplete markets relative to CM.

Finally, let's turn to the case in which goods are unit-elastic. If the elasticity is unity then relative price changes are completely offset by changes in output volumes. In this knife-edge case, the income effect of the required terms of trade depreciation (given the relatively higher productivity in Home) balances the incentive to switch expenditure towards Home goods: relative wealth is always unaffected in response to country specific shocks and that complete risk sharing is always obtained independent of the financial market structure assumed. ${ }^{22}$

Under sticky prices, it is costly for firms to change their prices which as a result don't adjust instantaneously. As is well known in the literature, a policy of producer price targeting would, however, lead to an exact replication of the flexible price allocation. If producer prices $P_{H}$ and $P_{F}^{*}$ are rigid, the policymaker can initiate the necessary policy response - a decrease in the nominal interest rate - that boosts demand and depreciates the home terms of trade, such that its response behaves as if there were flexible prices. Home goods are then cheaper relative to Foreign goods in both Home and the Foreign country. As demand shifts in favor of the goods with the lowest relative price, world consumption of Home goods increases relative to consumption of Foreign goods, that is, there is "expenditure switching". While the replication if the flex-price allocation is possible, the adjustment under sticky prices requires action on the part of the monetary policymaker. Also, if it is the optimal monetary policy to exactly replicate the flexible price allocation depends on the distortions that characterize the economy. As described in section 3 it should be expected that open economy aspects - the fact that countries have some degree of monopoly power over the terms of trade, and that the degree of international risk sharing may be too low - will generally have an influence on the degree of optimal stabilization that monetary policy should provide. The next sections studies these issues in detail.

\footnotetext{
${ }^{22}$ Strictly speaking, the threshold where relative price changes are completely offset by changes in output volumes lies only at unity because of my assumption of log-utility (that is a coefficient of relative risk aversion, $\sigma=1$ ). More generally this threshold depends on the intratemporal elasticity, the intertemporal elasticity and the degree of home bias and is given by $\omega=(2 \gamma-1+\sigma) /(2 \gamma \sigma)$.
} 


\section{THE ROLE OF FINANCIAL MARKET STRUCTURE AND THE TRADE ELASTICITY FOR STABILIZATION}

This section presents results on how the structure of international asset markets can change the way monetary policy should be conducted and analyzes the implications of the terms of trade considerations under these setups. Allowing for a non-unitary elasticity implies that terms-of-trade volatility becomes important in the consideration for optimal policy. The desire of adjusting the terms of trade (or the real exchange rate) is generally sufficient to induce the planner to deviate from a policy of full stabilization. As outlined in section 5 these considerations can drive the planner's behavior only in the presence of equilibrium fluctuations around the long-run steady state that derive from country-specific shocks. Therefore, the "optimal policy" is studied here in the sense of optimal stabilization in response to shocks. The shock considered throughout this section is a $1 \%$ increase in domestic productivity.

Figure 2 studies the optimal producer price inflation responses on impact of a the productivity shock, that is, it ignores the time dimension of the impulse response. These first-period responses are depicted instead as a function of the trade elasticity, which is given on the horizontal axis. The panels in the first row of the figure display the impact responses on a relatively small scale, which is useful to understand the pattern of inflation responses around the threshold of the unit-elasticity. The same figure is then reproduced a second time in the lower two panels, plotted on a larger scale, which turns out to be useful when studying the responses under incomplete markets and low elasticities. The vertical line at $\omega=0.33$ refers to the asymptotic threshold of $1-\frac{1}{2 \gamma}$ at which the sign of transmission switches and at which the volatility of the terms of trade is infinite, as discussed in section 4. Figure 3 displays the impact behavior of the nominal interest rate. The optimal impact responses of domestic and foreign producer price inflation are depicted over a large range of the elasticity of substitution between domestic and foreign goods (ranging from very complementary goods to very substitutable goods), and for the various scenarios of financial markets. A central result, which becomes immediately apparent upon inspecting Figure 2 is that, for all cases but the one of perfect risk sharing and coordination, the implications are that deviations from full (producer) price stability are optimal. While, independent of the financial market assumption, a policy of keeping producer price inflation at zero would replicate the flexible price outcome, this is found to be the optimal policy only in the case of complete markets and coordination, or in the special case of a unit elasticity and therefore automatic full risk sharing.

To better understand why this is the case I also study the responses of other variables of interest. Figures 4 and 5 therefore display the behavior of the terms of trade, the consumption and labor responses in the domestic economy under the various scenarios, by looking at differences of the responses of these variables to the responses that would occur in a flexible price version. ${ }^{23}$

As discussed previously, in response to a $1 \%$ productivity increase in the domestic economy, the terms of trade depreciate, channeling demand to the now more abundant domestic good, both under flexible prices or the sticky price optimal monetary policy economy. Figure 4 shows that in the case of complete financial markets under policy coordination the difference of the TOT response under optimal policy from the response under flexible prices is zero at all values of the trade elasticity. The TOT under CM and coordination responds exactly as in the flexible price world. Also, under the special case of a unit-elasticity, financial market structure becomes unimportant as perfect risk sharing is automatically obtained over compensating movements in the international relative price. For all other cases the responses of the sticky-price optimal and the flexible-price models differ: the terms of trade either appreciate (CM, Nash) or depreciate (FA, Nash and Cooperation) relative to the flexible price responses; as the monopoly power over the international relative price and/ or imperfect degrees of risk sharing also exert an influence on the optimal degree of stabilization.

In particular, the mechanism behind these patterns is as follows: under complete markets, when risk sharing is perfect and price stickiness is the only distortion in the economy, a coordinated policymaker that maximizes

\footnotetext{
${ }^{23}$ Alternatively, for the case of FA or IM, one could also study the differences of the responses of these variables with respect to the first best allocation.
} 
world welfare always finds it optimal to to replicate the flexible price allocation (as seen by the firm black line from Figure 2). However, when acting uncoordinated, the policymaker of each country fails to take into account the effect of his policy choice on the other country's welfare, and tries to make use of his monopoly power over the TOT. As a result the home authority finds it optimal to follow a policy in which the TOT vary somewhat less than under flexible prices if goods are substitutes: in response to the productivity increase the TOT is less depreciated relative to a flexible price outcome and producer price inflation is negative on impact. As consumption risk is shared and domestic goods can easily be substituted by foreign goods, the less pronounced TOT response aims at having to increase employment by a little less, which would be increasing their welfare, as this is done with the prospect of keeping the same utility from consumption. In a Nash equilibrium, however, this attempt is unsuccessful, as both policymakers have the incentive to let the terms of trade (or the real exchange rate) fluctuate less that what would be dictated by perfect risk sharing. As a result the TOT do not move 'enough', and while the uncoordinated planner succeeds in generating a lower volatility of labor effort, consumption volatility increases, which worsens overall welfare. ${ }^{24}$

When goods are complements, the incentive for the home policymaker to contract the employment response and push some of the work effort to the foreign economy is absent, as foreign goods consumption cannot substitute consumption of domestic goods. On the contrary, the incentive is to render foreign goods even cheaper. As a result, when goods are complements, producer price inflation is positive following the domestic productivity increase, and the TOT is more depreciated relative to its flexible price response. Only in the case of a unit elasticity of intratemporal substitution the economies are insular with respect to TOT movements and the Nash outcome and coordination deliver the same result (of a prescription of price stability as the optimal policy).

When turning to the scenario of financial autarky, the Ramsey planner now has to take another distortion into consideration in the design of its optimal policy as, in addition to nominal rigidities, the world is now one with a too low degree of international risk sharing. Figure 2 shows that the TOT is found to be more depreciated (compared to a flexible price scenario) when goods are substitutes, and the inflation response is positive. If a non-coordinated policymakers now were to reduce employment (volatility), this would still benefit agents by increasing the utility of leisure; unlike under complete markets, consumption risk is not shared and consumption is much more closely tied to current output. As productivity is currently high it pays off to increase output so much that the terms of trade depreciate even more than in the flexible price scenario. Under substitutes letting the TOT fluctuate more relative to the flexible price benchmark improves risk sharing and pushes the TOT response somewhat closer towards how it would respond in a complete markets-perfect risk sharing world. The higher TOT volatility therefore translates into a lower consumption volatility which improves welfare relative to flexible prices.

Only in the case where goods are complements domestic agents have an incentive to let their terms of trade depreciate somewhat less (appreciate relative to a flex price world) and to contract output relative to the flexible price outcome. As a result, the prescription of an optimal policy flips again when crossing the area from goods being substitutes into the complementarity region: in the latter case the TOT is found to be more appreciated relative to the flexible price response and producer price inflation decreases in response to a productivity shock.

It is interesting to note, that under financial autarky the optimal policy of both the coordinated and uncoordinated policymakers have the same qualitative implications of deviating from price stability. While even an uncoordinated planner finds it optimal to 'do some risk sharing', a coordinated policymaker will find it optimal to depreciate the terms of trade even more when goods are complements, taking account of the fact that production should take place in the more productive economy and that over a lower price of domestic goods both economies benefit (similarly, the coordinated planner will find it optimal to appreciate the terms of trade even more relative to the flex price case when goods are substitutes). When studying flexible

\footnotetext{
${ }^{24}$ It should be stressed that the result documented is in terms of volatilities. In particular, for a negative productivity shock the optimal TOT response under the optimal policy of an uncoordinated policymaker would be to generate a TOT appreciation that is less pronounced than under flexible prices. A policymaker under commitment cannot resort to ex-post terms of trade appreciation.
} 
price impulse responses in section 5 under the various financial market scenarios, the TOT under incomplete markets (financial autarky or bond economy) was shown to depreciate too little (relative to the efficient economy with risk sharing) when goods are substitutes, but depreciate too much when goods are complements. A planner that, because of the presence of price rigidities, has some control over the terms of trade (or the real exchange rate), will therefore find it optimal to push it closer to the responses that would prevail in the complete markets case, thereby obtaining some risk sharing through the relative price. Policymakers under a sticky-price incomplete financial markets can therefore improve over the flex-price (but incomplete markets) outcome.

Finally, in the incomplete markets-bond economy case, the optimal responses to a domestic productivity shock lie, as should be expected, somewhere in between the cases of complete markets and financial autarky. This finding is not surprising, considering that the availability of the international bond allows for some consumption smoothing. In turn, how easily the bond can be used in consumption smoothing depend crucially on the parameter of the portfolio adjustment cost, $\psi$. As $\psi$ becomes very large, the policy prescriptions will closely follow the ones under financial autarky, if $\psi$ is very small the optimal policy in the bond economy will be closer to the complete markets case. With the chosen value, it turns out that a policymaker under Nash competition follows a policy that is closer to the full risk sharing case, while a coordinated policymaker's policy matches closer that under financial autarky.

\section{THE ROLE OF RISK SHARING FOR GAINS FROM POLICY COORDINATION AND GAINS OVER THE FLEXIBLE PRICE ALLOCATION}

The fact that the policy prescription under Nash competition generally differs from the policy prescription under coordination implies that there are welfare gains from coordination. The welfare measures computed are conditional welfare, measured in terms of consumption equivalents. ${ }^{25}$ While it should be noted that, as the steady state level of inflation is non-distorted, welfare gains are found generally to be very small, Table 2 shows that these are found increasing for elasticities of substitution away from unity and typically by an order of magnitude larger in the case of complementarity between domestic and foreign goods. Moreover, comparing complete markets with financial autarky welfare gains from coordination are typically larger under complete markets as long as goods are substitutes, as documented also by Sutherland (2004). The case is different, however, when domestic and foreign goods are complementary in consumption. When goods are complements and the elasticity of substitution is very low, wealth effects from movements in the international relative price become very large under financial autarky. The relative price distortion, that results in the too low degree of international risk sharing, becomes particularly important when the trade elasticity is close to the threshold $1-1 / 2 \gamma$, as discussed earlier. As a result, a coordinated planner, attributes a much higher importance to alleviating the relative price distortion, trying to improve international risk sharing, and can achieve much larger welfare gains. It is of particular importance to include this region in a study of the effects of the degree of international risk sharing on optimal monetary policy, as this is the region of the trade elasticity which is able to reconcile the empirically observed lack of risk sharing with the model. The conclusion is therefore, that when risk sharing is low, gains from a international coordination of policies can be substantial.

\footnotetext{
${ }^{25}$ That is, I compute the $\lambda$ variation in consumption that makes welfare under the Nash policy equivalent to the welfare under coordination. Formally, letting superscripts $N$ and $C$ stand for the scenario of Nash policy and cooperation respectively,$$
\frac{1}{2}\left(W_{t}^{N}+W_{t}^{* N}\right)=\frac{1}{2}\left[E_{t} \sum_{t=k}^{\infty} \beta^{k}\left\{\log \left[C_{k}^{C}(1-\lambda)\right]-\frac{\left(L_{k}^{C}\right)^{1+\chi}}{1+\chi}+\log \left[C_{k}^{* C}(1-\lambda)\right]-\frac{\left(L_{k}^{* C}\right)^{1+\chi}}{1+\chi}\right\}\right],
$$$$
\text { from which } \lambda \text { can be found as: }
$$$$
\lambda=1-\exp \left[\frac{1}{2}\left(W_{t}^{N}+W_{t}^{* N}\right)-W_{C, t}^{C}-W_{C, t}^{C *}+W_{L, t}^{C}+W_{L, t}^{C *}\right],
$$$$
\text { where } W_{C, t}^{C}=E_{t} \sum_{t=k}^{\infty} \beta^{k} \log C_{k}^{C} \text { and } W_{L, t}^{C}=E_{t} \sum_{t=k}^{\infty} \beta^{k} \frac{\left(L_{k}^{C}\right)^{1+x}}{1+x} \text {. }
$$ 
Finally, the finding that even a coordinated policymaker finds it optimal not to replicate the flexible price equilibrium means that there are welfare gains over the flexible price allocation whenever risk sharing is incomplete. A planner under incomplete markets (financial autarky or the bond economy) can improve upon the flexible price allocation by pushing the real exchange towards the case of perfect risk sharing. Table 3 computes the welfare gains of the various financial market regimes over the flexible price allocation, to give an indication of the quantitative importance of this finding. Clearly, under complete markets Nash competition leads to welfare losses over a flexible price (efficient) allocation. Interestingly, under financial autarky or the IM-bond economy even Nash policymakers, even though they choose an inefficient level of the terms of trade volatility, are able to achieve welfare gains over a flexible price allocation.

\section{SENSITIVITY ANALYSIS}

In this section I perform some sensitivity analysis on the baseline parameter choice discussed in section 4 . Table 4 and 5 summarize the results of this analysis on the welfare gains from coordination and the welfare gains over the flexible price allocation, respectively. For the sake of saving space, Table 5 is limited to the more interesting cases of FA and IM under coordination only. The findings can be summarized as follows.

Higher values of the coefficient of relative risk aversion tend to lead to higher welfare gains, both welfare gains from coordination, and - under incomplete markets - for gains from deviation from price stability. Moreover, deviating from the assumption of log-preferences implies that the threshold at which the optimal policy coincide irrespective of financial market structure moves to a lower value of the trade elasticity. In particular, the relevant combination of both intra- and intertemporal substitution elasticities (and the degree of home bias) lie at $\omega=(2 \gamma-1+\sigma) /(2 \gamma \sigma)$, which for values $\sigma=2$ and $\sigma=3$ are at $\omega=0.83$ and $\omega=.78$ respectively. Figure 7 summarizes this result graphically, by plotting the the differences of the TOT impact responses from the flexible price allocation for these cases.

As regards the parameter of the degree of home bias, I find that for the case of substitutes lower values of home bias result in higher welfare gains, consistent with with finding of previous work (e.g. Faia \& Monacelli (2004)). For the case of complementary goods, however, a higher degree of home bias leads to larger welfare gains. Moreover, as summarized in Figure 8, the level of the asymptotic threshold at which the risk sharing becomes increasingly worse under incomplete financial markets shift.

For increasing values of $x$ compared to the baseline, which implies a lower labor supply elasticity, the welfare gains generated by model are generally smaller welfare gains. This is because higher values of $x$ increase the negative welfare effect of labor volatility and reduce the uncoordinated policymaker's incentive to engage in this form of policy.

Turning to the parameters on the production side, a higher persistence, $\rho$, or a higher standard deviation of the productivity shock, $\sigma_{\varepsilon}$, as well as higher price adjustment costs, $\alpha$, all tend to increase welfare gains.

Finally, I also consider variations in the production subsidy, $\tau$, contrasting the baseline case in which the subsidy is fully offset with the case where the subsidy is zero and the monopolistic competition distortion is present. In the latter case there is a motive for a policymaker to also address this distortion in response to productivity shocks that hit the economy. In particular, while for goods being substitutes the presence of the monopolistic competition distortion leads to a decrease in the achievable welfare gains - as the incentive to push the economy towards the efficient level of output in response to shocks runs counter to the incentive to moving the terms of trade in one's favor -, the case is again the opposite in the region of complementary goods. 


\section{Conclusion}

The analysis of this paper has shown that the elasticity of intratemporal substitution and assumptions on the international financial market structure are important determinants of optimal monetary policy in the open economy. In particular, a purely inward-looking policy of producer price stability is found to be optimal only in the very special case in which financial markets are complete and policymakers act coordinately, or in the case of a unit trade elasticity which provides automatic perfect risk sharing. In all other cases it is optimal for monetary policymaker to not only consider stabilizing internal prices but to consider also the variability of international prices as the terms of trade (or the real exchange rate) in shaping their policy. In all but the special case of the unit elasticity, there are gains from policy coordination to be achieved, which become quite substantial when the trade elasticity is low and financial markets are incomplete. 


\section{References}

ATKinson, A. B. \& J. E. STIGLiTZ (1976). "The design of tax structure: Direct versus indirect taxation." Journal of Public Economics, 6 (1-2), 55-75.

BackUs, D. K., P. J. Kehoe \& F. E. Kydland (1995). "International Business Cycles: Theory and Evidence." In T. F. Cooley, editor, "Frontiers of Business Cycle Research," 331-56. Princeton University Press.

Benigno, G. \& P. Benigno (2003). "Price Stability in Open Economies." Review of Economic Studies, 70 (4), 743-764.

BENIGNO, P. (2001). "Price stability with imperfect financial integration." CEPR Discussion Paper, 2854.

BEnigno, P. (2009). "Price stability with imperfect financial integration." Journal of Money, Credit and Banking, 41 (s1), 121-149.

Benigno, P. \& M. Woodford (2005). "Inflation Stabilization and Welfare: The Case of Large Distortions." Journal of the European Economic Association, 3, 1185-1236.

Chari, V. V. \& P. J. Kehoe (1999). “Optimal fiscal and monetary policy.” In J. B. Taylor \& M. Woodford, editors, "Handbook of Macroeconomics,”, volume 11671-1745.

Chari, V. V., L. J. Christiano \& P. J. Kehoe (1991). "Optimal Fiscal and Monetary Policy: Some Recent Results." Journal of Money, Credit and Banking, 23 (3), 519-39.

Chari, V. V., P. J. Kehoe \& E. R. MCGratTAn (2002). "Can sticky price models generate volatile and persistent real exchange rates?” Review of Economic Studies, 69, 633-63.

Clarida, R., J. Galí \& M. Gertler (2001). "Optimal Monetary Policy in Closed versus Open Economies: An Integrated Approach." American Economic Review Papers and Proceedings, 91 (2), 248252.

Cole, H. L. \& M. OBSTFELD (1991). "Commodity trade and international risk sharing: How much do financial markets matter?” Journal of Monetary Economics, 28, 3-24.

CORsetTi, G. \& P. PeSEnTi (2001). “Welfare And Macroeconomic Interdependence.” Quarterly Journal of Economics, 116 (2), 421-445.

Corsetti, G., L. Dedola \& S. Leduc (2008). "International Risk Sharing and the Transmission of Productivity Shocks.” Review of Economic Studies, 75 (2), 443-473.

Corsetti, G., L. Dedola \& S. Leduc (2009). "Demand Imbalances, Exchange Rate Misalignment and Monetary Policy." mimeo.

De PaOli, B. (2009). "Monetary Policy in a Small Open Economy: the Role of Asset Market Structure." Journal of Money, Credit and Banking, forthcoming.

Devereux, M. B. \& A. Sutherland (2008). "Country Portfolios in Open Economy Macro Models." NBER Working Paper, 14372.

Enders, Z. \& G. Mueller (2009). “On the International Transmission of Technology Shocks.” Journal of International Economics, 78, 45-59.

FAIA, E. \& T. MONACELLI (2004). "Ramsey monetary policy and international prices.” ECB Working Paper, 344. 
FAiA, E. \& T. MONACELli (2008). “Optimal Monetary Policy in a Small Open Economy with Home Bias.” Journal of Money, Credit and Banking, 40 (4), 721-750.

Galí, J. \& T. Monacelli (2005). "Monetary Policy and Exchange Rate Volatility in a Small Open Economy.” Review of Economic Studies, 72 (3), 707-734.

Heathcote, J. \& F. PerRi (2002). "Financial Autarky and International Business Cycles." Journal of Monetary Economics, 49, 601-627.

Khan, A., R. G. King \& A. L. Wolman (2003). “Optimal Monetary Policy.” Review of Economic Studies, $70(4), 825-860$.

LaI, H. \& D. Trefler (2002). "The Gains from Trade with Monopolistic Competition: Specification, Estimation, and Mis-Specification.” NBER Working Papers, 9169.

LIU, Z. \& E. PAPPA (2008). “Gains from Coordination in a Multi-Sector Open Economy: Does it Pay to be Different?” Journal of Economic Dynamics and Control, 32 (7), 2085-2117.

LUCAS, R. J. \& N. L. STOKEY (1983). “Optimal fiscal and monetary policy in an economy without capital.” Journal of Monetary Economics, 12 (1), 55-93.

Ramsey, F. P. (1927). “A Contribution to the Theory of Taxation.” Economic Journal, 37, 47-61.

Rotemberg, J. \& M. Woodford (1997). “An Optimization-Based Econometric Framework for the Evaluation of Monetary Policy.” NBER Macroeconomics Annual, 12, 297-361.

SCHMiTT-GROHÉ, S. \& M. URIBE (2003). “Closing small open economy models.” Journal of International Economics, 61 (1), 163-185.

SchmitT-Grohé, S. \& M. URibe (2005). "Optimal Fiscal and Monetary Policy in a Medium-Scale Macroeconomic Model.” NBER Macroeconomics Annual, 383-425.

Schmitt-Grohé, S. \& M. Uribe (2007). "Optimal Simple And Implementable Monetary and Fiscal Rules.” Journal of Monetary Economics, 54, 1702-1725.

SchmitT-Grohé, S. \& M. URIBE (2009). "Computing Ramsey Equilibria in Medium-Scale Macroeconomic Models." mimeo.

Sutherland, A. (2004). "International Monetary Policy Coordination and Financial Market Integration." CEPR Discussion Papers, 4251.

Thoenissen, C. (2008). "Exchange rate dynamics, asset market structure and the role of the trade elasticity." CDMA Working Paper Series, 0803.

Tille, C. \& E. VAN Wincoop (2007). “International Capital Flows.” NBER Working Paper, 12856.

Woodford, M. (2003). Interest and Prices: Foundations of a Theory of Monetary Policy. Princeton, NJ: Princeton University Press. 


\section{Appendices}

\section{A Tables and Figures}

\section{Table 1}

Model Parameters

\begin{tabular}{lll}
\hline discount factor & $\beta$ & 0.99 \\
elasticity between varieties & $\theta$ & 6 \\
home bias & $\gamma, 1-\gamma^{*}$ & 0.75 \\
persistence of productivity shock & $\rho, \rho^{*}$ & 0.95 \\
standard deviation of productivity shock & $\sigma_{\varepsilon}, \sigma_{\varepsilon}^{*}$ & 0.01 \\
coefficient of relative risk aversion & $\sigma$ & 1 \\
inverse of the elasticity of labor supply & $\chi$ & 2 \\
Rotemberg price adjustment cost parameter & $\alpha$ & 60 \\
Production subsidy offsetting monopolistic competition distortion & $\tau$ & $1 /(\theta-1)$ \\
Portfolio adjustment cost parameter & $\psi$ & 0.00074 \\
trade elasticity between $H$ and $F$ consumption goods & $\omega$ & $\epsilon[0.15,5]$ \\
\hline
\end{tabular}

\section{Table 2}

Welfare gains from monetary policy coordination, in percent of st.st. consumption

\begin{tabular}{llrrr}
\hline$\omega$ & & CM & FA & \multicolumn{1}{c}{ IM } \\
0.15 & $1 \mathrm{e}-2 *$ & 0.0191 & 0.6892 & 0.9311 \\
0.25 & $1 \mathrm{e}-2 *$ & 0.0106 & 7.5072 & 12.0912 \\
0.45 & $1 \mathrm{e}-2 *$ & 0.0024 & 0.5393 & 2.2871 \\
0.55 & $1 \mathrm{e}-2 *$ & 0.0016 & 0.0079 & 0.0819 \\
0.65 & $1 \mathrm{e}-2 *$ & 0.0007 & 0.0014 & 0.0117 \\
0.85 & $1 \mathrm{e}-2 *$ & 0.0001 & 0.0002 & 0.0004 \\
1 & $1 \mathrm{e}-2 *$ & 0 & 0 & 0 \\
1.5 & $1 \mathrm{e}-2 *$ & 0.0002 & 0.0001 & 0.0003 \\
2 & $1 \mathrm{e}-2 *$ & 0.0002 & 0.0001 & 0.0004 \\
3 & $1 \mathrm{e}-2 *$ & 0.0000 & 0.0001 & 0.0004 \\
5 & $1 \mathrm{e}-2 *$ & 0.0009 & 0.0000 & 0.0004 \\
\hline
\end{tabular}




\section{Table 3}

Welfare gains from optimal policy over flexible price allocation, in percent of st.st. consumption

\begin{tabular}{llrrrrrr}
\hline & \multicolumn{4}{c}{ policy coordination } & \multicolumn{3}{c}{ Nash policy } \\
$\omega$ & & CM & \multicolumn{1}{c}{ FA } & \multicolumn{1}{c}{ IM } & CM & \multicolumn{1}{c}{ FA } & \multicolumn{1}{c}{ IM } \\
0.15 & $1 \mathrm{e}-2^{*}$ & 0 & 1.8724 & 1.7174 & -0.0191 & 1.1831 & 0.7861 \\
0.25 & $1 \mathrm{e}-2^{*}$ & 0 & 18.9492 & 17.6112 & -0.0106 & 11.4277 & 5.4986 \\
0.45 & $1 \mathrm{e}-2^{*}$ & 0 & 1.3409 & 0.9617 & -0.0024 & 0.8015 & -1.3256 \\
0.55 & $1 \mathrm{e}-2^{*}$ & 0 & 0.3427 & 0.2407 & -0.0016 & 0.3348 & 0.1588 \\
0.65 & $1 \mathrm{e}-2^{*}$ & 0 & 0.0521 & 0.0370 & -0.0007 & 0.0507 & 0.0253 \\
0.85 & $1 \mathrm{e}-2^{*}$ & 0 & 0.0015 & 0.0011 & -0.0001 & 0.0013 & 0.0007 \\
1 & $1 \mathrm{e}-2^{*}$ & 0 & 0 & 0 & 0 & 0 & 0 \\
1.5 & $1 \mathrm{e}-2^{*}$ & 0 & 0.0006 & 0.0006 & -0.0002 & 0.0005 & 0.0003 \\
2 & $1 \mathrm{e}-2^{*}$ & 0 & 0.0006 & 0.0006 & -0.0002 & 0.0005 & 0.0002 \\
3 & $1 \mathrm{e}-2^{*}$ & 0 & 0.0004 & 0.0004 & -0.0000 & 0.0003 & 0.0008 \\
5 & $1 \mathrm{e}-2^{*}$ & 0 & 0.0002 & 0.0002 & -0.0009 & 0.0001 & -0.0002 \\
\hline
\end{tabular}

\section{Table 4}

Sensitivity analysis on welfare gains from coordination, in percent of st.st. consumption

\begin{tabular}{lcccccccccc}
\hline$\omega$ & & & $\mathrm{CM}$ & & & $\mathrm{FA}$ & & \multicolumn{3}{c}{$\mathrm{IM}$} \\
& & $\sigma=1$ & $\sigma=2$ & $\sigma=3$ & $\sigma=1$ & $\sigma=2$ & $\sigma=3$ & $\sigma=1$ & $\sigma=2$ & $\sigma=3$ \\
0.65 & $1 \mathrm{e}-2^{*}$ & 0.0007 & 0.0002 & 0.0012 & 0.0014 & 0.0023 & 0.0033 & 0.0117 & 0.0201 & 0.0306 \\
1 & $1 \mathrm{e}-2^{*}$ & 0 & 0.0008 & 0.0014 & 0.0001 & 0.0015 & 0.0038 & 0.0004 & 0.0021 & 0.0053 \\
2 & $1 \mathrm{e}-2^{*}$ & 0.0002 & 0.0000 & 0.0000 & 0.0001 & 0.0008 & 0.0013 & 0.0004 & 0.0019 & 0.0027 \\
& & $\gamma=.6$ & $\gamma=.75$ & $\gamma=.9$ & $\gamma=.6$ & $\gamma=.75$ & $\gamma=.9$ & $\gamma=.6$ & $\gamma=.75$ & $\gamma=.9$ \\
0.65 & $1 \mathrm{e}-2^{*}$ & 0.0006 & 0.0007 & 0.0002 & 0.0004 & 0.0014 & 0.0042 & 0.0033 & 0.0117 & 0.0177 \\
2 & $1 \mathrm{e}-2^{*}$ & 0.0001 & 0.0002 & 0.0004 & 0.0003 & 0.0001 & 0.0000 & 0.0006 & 0.0004 & 0.0003 \\
& & $\chi=1$ & $\chi=2$ & $\chi=3$ & $\chi=1$ & $\chi=2$ & $\chi=3$ & $\chi=1$ & $\chi=2$ & $\chi=3$ \\
0.65 & $1 \mathrm{e}-2^{*}$ & 0.0013 & 0.0007 & 0.0005 & 0.0050 & 0.0014 & 0.0005 & 0.0209 & 0.0117 & 0.0089 \\
2 & $1 \mathrm{e}-2^{*}$ & 0.0001 & 0.0002 & 0.0001 & 0.0003 & 0.0001 & 0.0001 & 0.0007 & 0.0004 & 0.0004 \\
& & & $\rho=.95$ & $\rho=.99$ & & $\rho=.95$ & $\rho=.99$ & & $\rho=.95$ & $\rho=.99$ \\
0.65 & $1 \mathrm{e}-2^{*}$ & 0.0007 & 0.0007 & 0.0007 & 0.0013 & 0.0014 & 0.0016 & 0.0146 & 0.0117 & 0.0037 \\
2 & $1 \mathrm{e}-2^{*}$ & 0.0002 & 0.0002 & 0.0002 & 0.0001 & 0.0001 & 0.0001 & 0.0006 & 0.0004 & 0.0002 \\
& & $\sigma=.005$ & $\sigma \varepsilon=.01$ & $\sigma \varepsilon=.1$ & $\sigma \varepsilon=.005$ & $\sigma=.01$ & $\sigma \varepsilon=.1$ & $\sigma \varepsilon=.005$ & $\sigma \varepsilon=.01$ & $\sigma \varepsilon=.1$ \\
0.65 & $1 \mathrm{e}-2^{*}$ & 0.0002 & 0.0007 & 0.0710 & 0.0004 & 0.0014 & 0.1436 & 0.0029 & 0.0117 & 1.1738 \\
2 & $1 \mathrm{e}-2^{*}$ & 0.0000 & 0.0002 & 0.0154 & 0.0000 & 0.0001 & 0.0132 & 0.0001 & 0.0004 & 0.0441 \\
& & $\tau=\frac{1}{\theta-1}$ & $\tau=0$ & & $\tau=\frac{1}{\theta-1}$ & $\tau=0$ & & $\tau=\frac{1}{\theta-1}$ & $\tau=0$ & \\
0.65 & $1 \mathrm{e}-2^{*}$ & 0.0007 & 0.0008 & & 0.0014 & 0.0011 & & 0.0117 & 0.0107 & \\
2 & $1 \mathrm{e}-2^{*}$ & 0.0002 & 0.0002 & & 0.0001 & 0.0001 & & 0.0004 & 0.0004 & \\
& & $\alpha=40$ & $\alpha=60$ & $\alpha=80$ & $\alpha=40$ & $\alpha=60$ & $\alpha=80$ & $\alpha=40$ & $\alpha=60$ & $\alpha=80$ \\
0.65 & $1 \mathrm{e}-2^{*}$ & 0.0005 & 0.0007 & 0.0009 & 0.0012 & 0.0014 & 0.0016 & 0.0123 & 0.0117 & 0.0122 \\
2 & $1 \mathrm{e}-2^{*}$ & 0.0001 & 0.0002 & 0.0002 & 0.0001 & 0.0001 & 0.0002 & 0.0005 & 0.0004 & 0.0004 \\
\hline & & & & & & & & & &
\end{tabular}




\section{Table 5}

Sensitivity analysis, welfare gains over flexible prices, in percent of st.st. consumption

\begin{tabular}{lccccccc}
\hline$\omega$ & & & FA & & & IM & \\
& & $\sigma=1$ & $\sigma=2$ & $\sigma=3$ & $\sigma=1$ & $\sigma=2$ & $\sigma=3$ \\
0.65 & $1 \mathrm{e}-02 *$ & 0.0521 & 0.0606 & 0.0704 & 0.0370 & 0.0394 & 0.0421 \\
1 & $1 \mathrm{e}-02 *$ & 0 & 0.0015 & 0.0038 & 0 & 0.0012 & 0.0028 \\
2 & $1 \mathrm{e}-02 *$ & 0.0006 & 0.0014 & 0.0017 & 0.0006 & 0.0014 & 0.0014 \\
& & $\gamma=.6$ & $\gamma=.75$ & $\gamma=.9$ & $\gamma=.6$ & $\gamma=.75$ & $\gamma=.9$ \\
0.65 & $1 \mathrm{e}-02 *$ & 0.0389 & 0.0521 & 0.0332 & 0.0331 & 0.0370 & 0.0107 \\
2 & $1 \mathrm{e}-02 *$ & 0.0017 & 0.0006 & 0.0001 & 0.0017 & 0.0006 & 0.0001 \\
& & $\chi=1$ & $\chi=2$ & $\chi=3$ & $\chi=1$ & $\chi=2$ & $\chi=3$ \\
0.65 & $1 \mathrm{e}-02 *$ & 0.0971 & 0.0521 & 0.0327 & 0.0723 & 0.0370 & 0.0227 \\
2 & $1 \mathrm{e}-02 *$ & 0.0012 & 0.0006 & 0.0004 & 0.0013 & 0.0006 & 0.0004 \\
& & $\rho=.9$ & $\rho=.95$ & $\rho=.99$ & $\rho=.9$ & $\rho=.95$ & $\rho=.99$ \\
0.65 & $1 \mathrm{e}-02 *$ & 0.0510 & 0.0521 & 0.0531 & 0.0237 & 0.0370 & 0.0531 \\
2 & $1 \mathrm{e}-02 *$ & 0.0006 & 0.0006 & 0.0006 & 0.0006 & 0.0006 & 0.0006 \\
& & $\sigma_{\varepsilon}=.005$ & $\sigma \varepsilon=.01$ & $\sigma \varepsilon=.1$ & $\sigma_{\varepsilon}=.005$ & $\sigma=.01$ & $\sigma \varepsilon=.1$ \\
0.65 & $1 \mathrm{e}-02 *$ & 0.0130 & 0.0521 & 5.2101 & 0.0093 & 0.0370 & 3.7044 \\
2 & $1 \mathrm{e}-02 *$ & 0.0002 & 0.0006 & 0.0619 & 0.0002 & 0.0006 & 0.0623 \\
& & $\tau=\frac{1}{\theta-1}$ & $\tau=0$ & & $\tau=\frac{1}{\theta-1}$ & $\tau=0$ & \\
0.65 & $1 \mathrm{e}-02 *$ & 0.0521 & 0.0564 & & 0.0370 & 0.0408 & \\
2 & $1 \mathrm{e}-02 *$ & 0.0006 & 0.0007 & & 0.0006 & 0.0006 & \\
& & $\alpha=40$ & $\alpha=60$ & $\alpha=80$ & $\alpha=40$ & $\alpha=60$ & $\alpha=80$ \\
0.65 & $1 \mathrm{e}-02 *$ & 0.0392 & 0.0521 & 0.0630 & 0.0273 & 0.0370 & 0.0454 \\
2 & $1 \mathrm{e}-02 *$ & 0.0005 & 0.0006 & 0.0008 & 0.0005 & 0.0006 & 0.0008 \\
\hline
\end{tabular}


Figure 1

Impulse responses to a domestic productivity shock under flexible prices
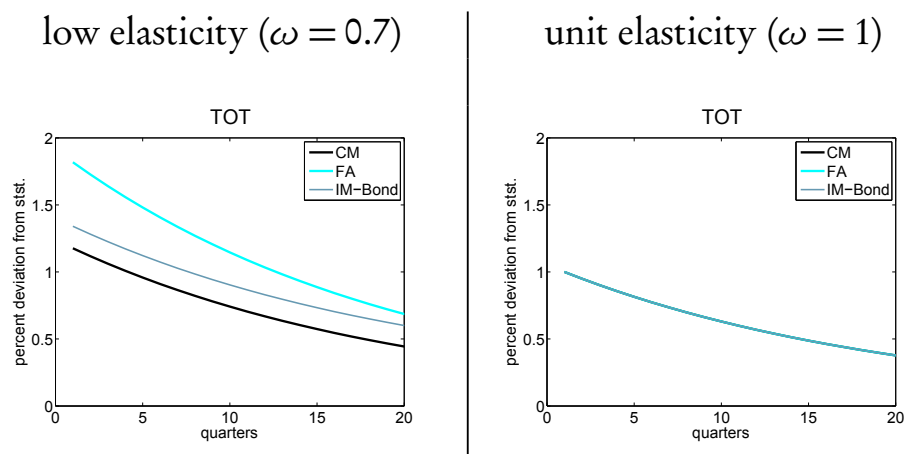

high elasticity $(\omega=3)$
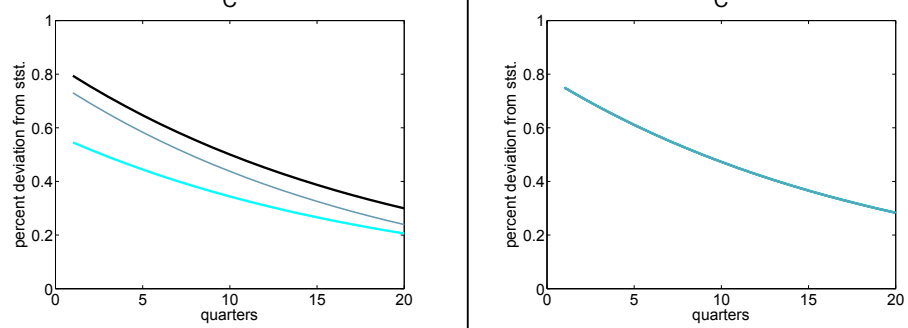

$C^{*}$
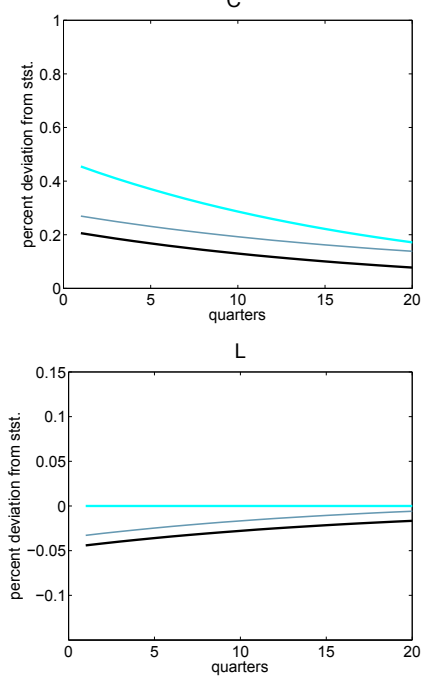

$\mathrm{L}^{*}$
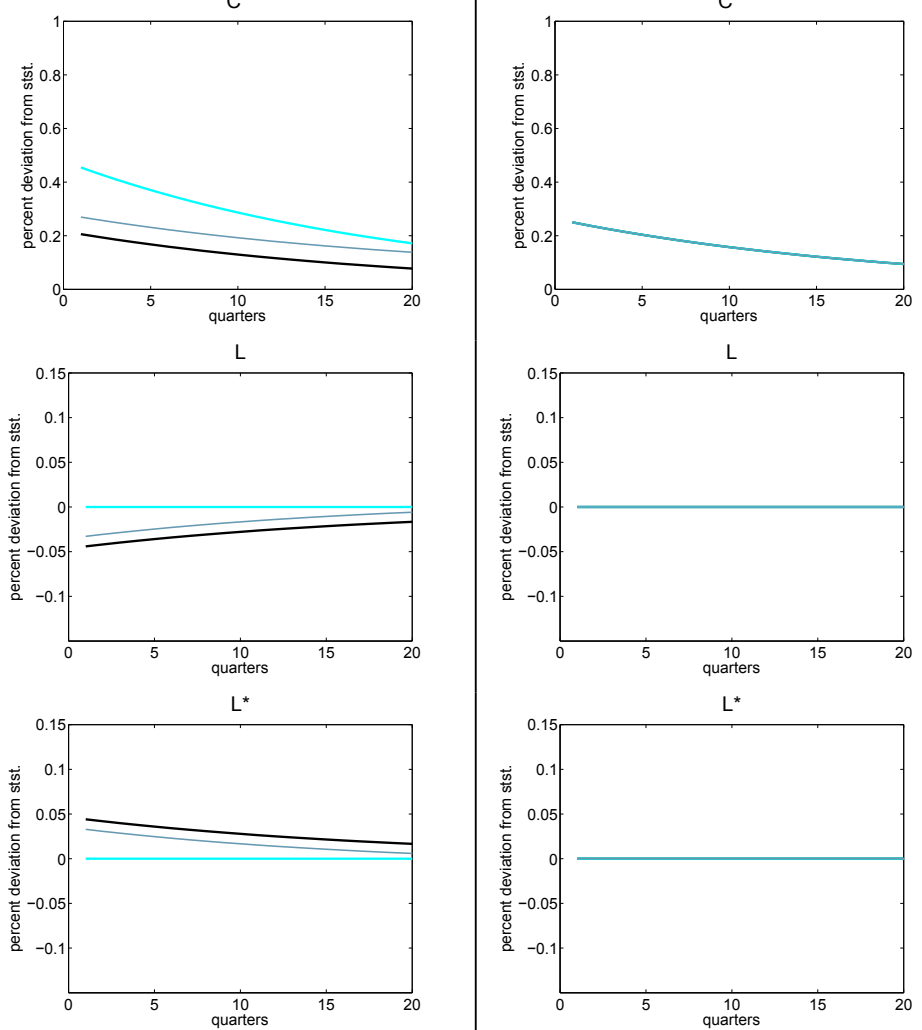

$\mathrm{L}^{*}$
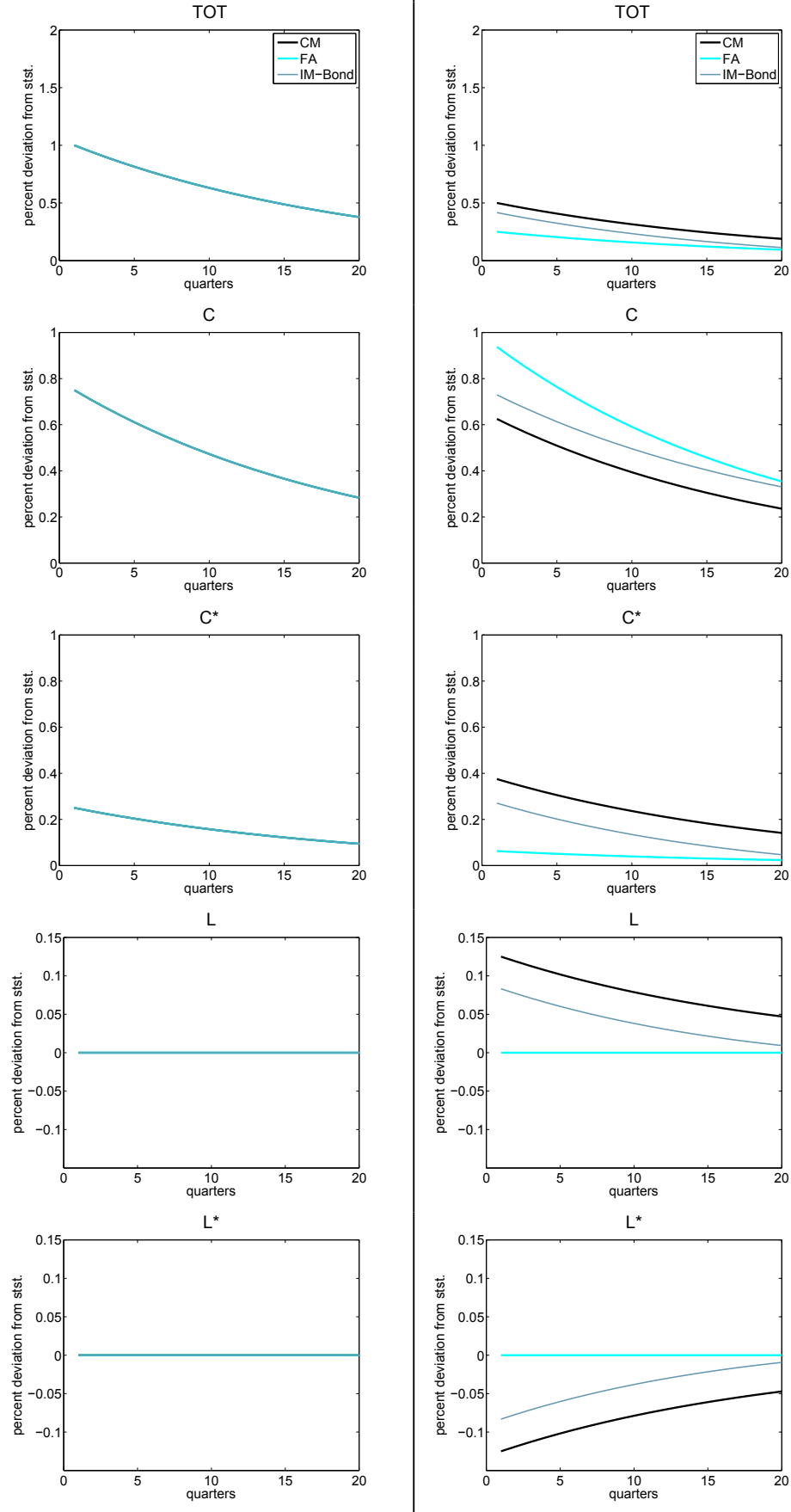

$\mathrm{C}^{*}$
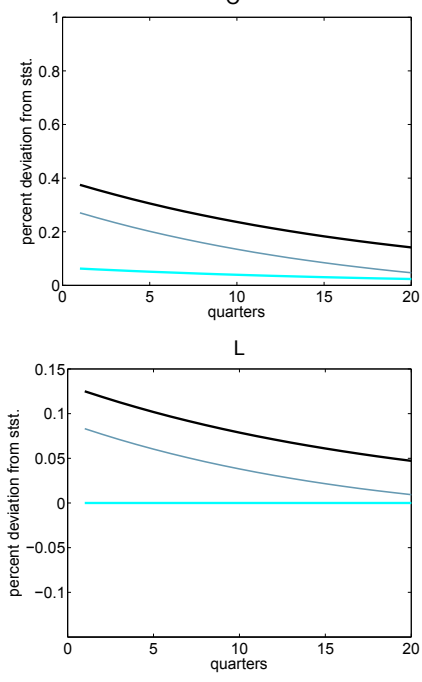

$L^{*}$

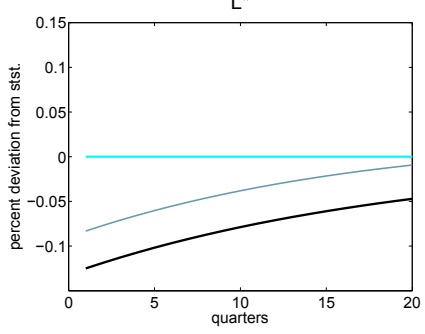


Figure 2

Impact responses of optimal domestic and foreign producer price inflation to a domestic $1 \%$ productivity shock
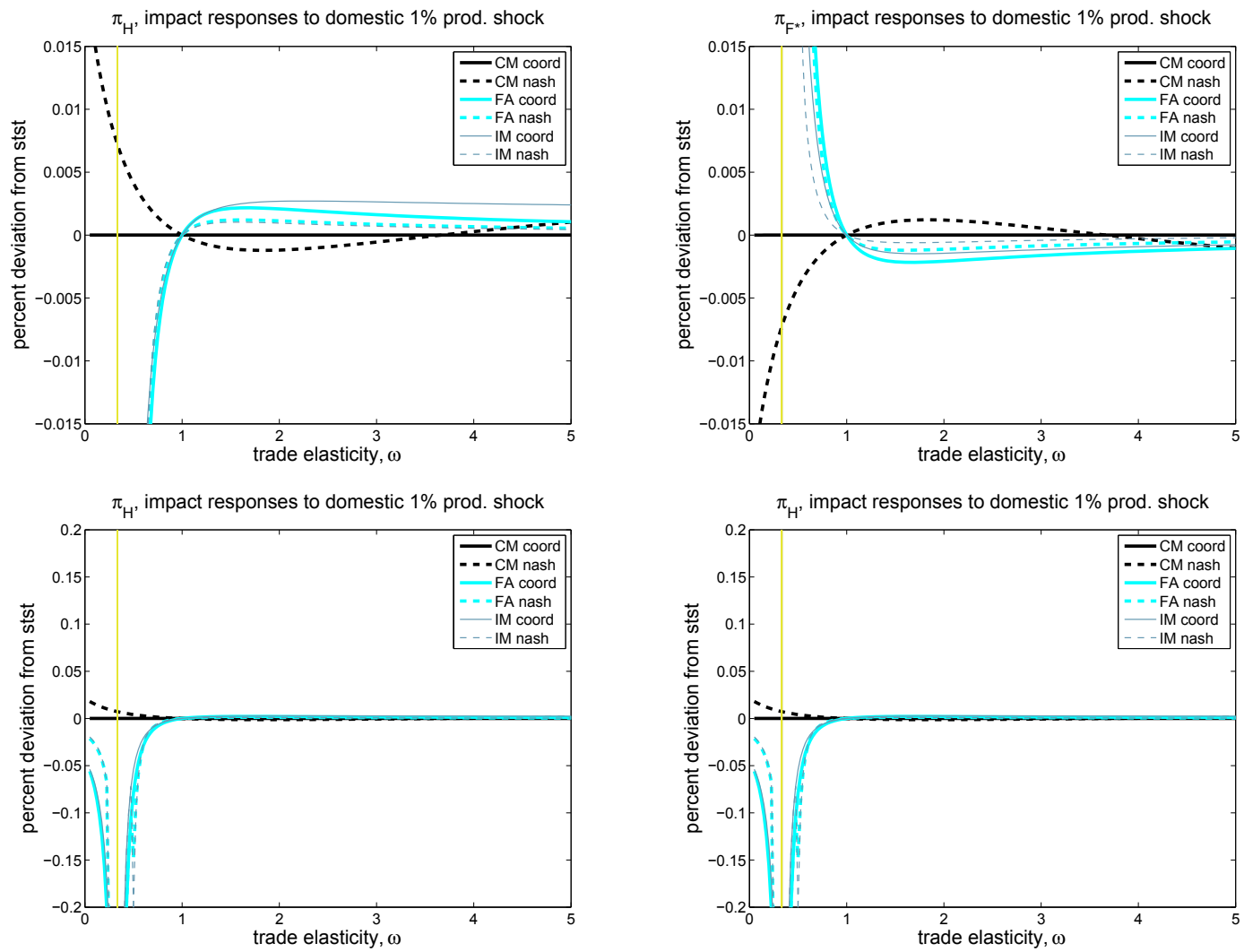

1st row: small scale on the axis of the ordinate

2nd row: same figures as row one but plotted on a larger scale 
Figure 3

Impact responses of optimal domestic and foreign nominal interest rates to a domestic $1 \%$ productivity shock
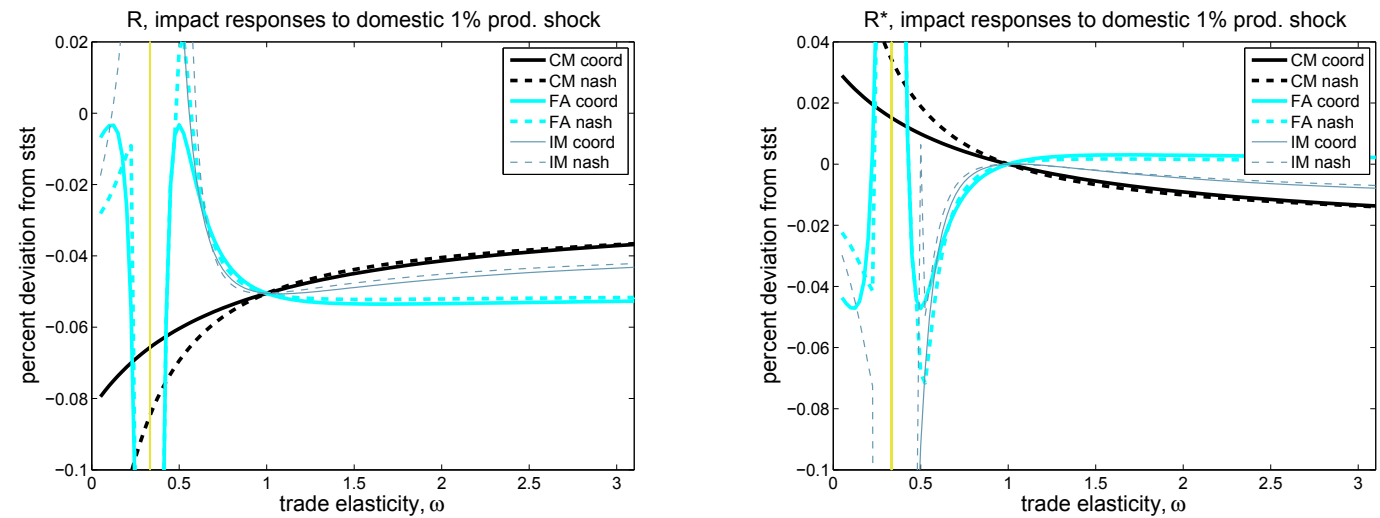

\section{Figure 4}

Differences of optimal TOT impact responses over flexible price TOT impact responses (to a domestic $1 \%$ productivity shock), depending on the trade elasticity
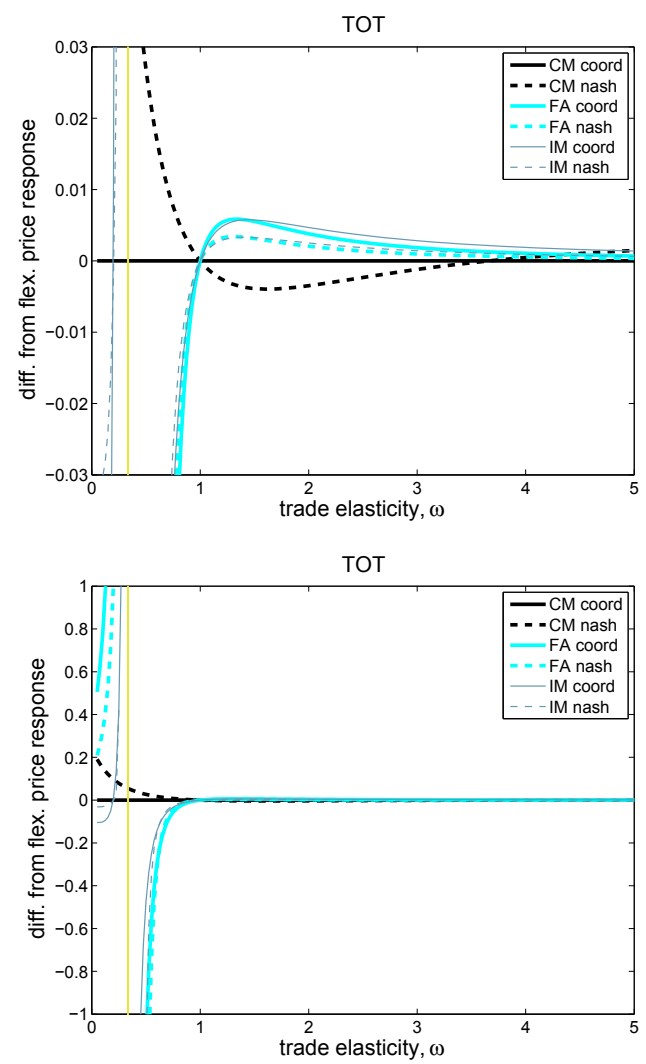

1st row: small scale on the axis of the ordinate

2nd row: same figures as row one but plotted on a larger scale 


\section{Figure 5}

Differences of optimal consumption impact responses over flexible price impact responses (to a domestic $1 \%$ productivity shock), depending on the trade elasticity
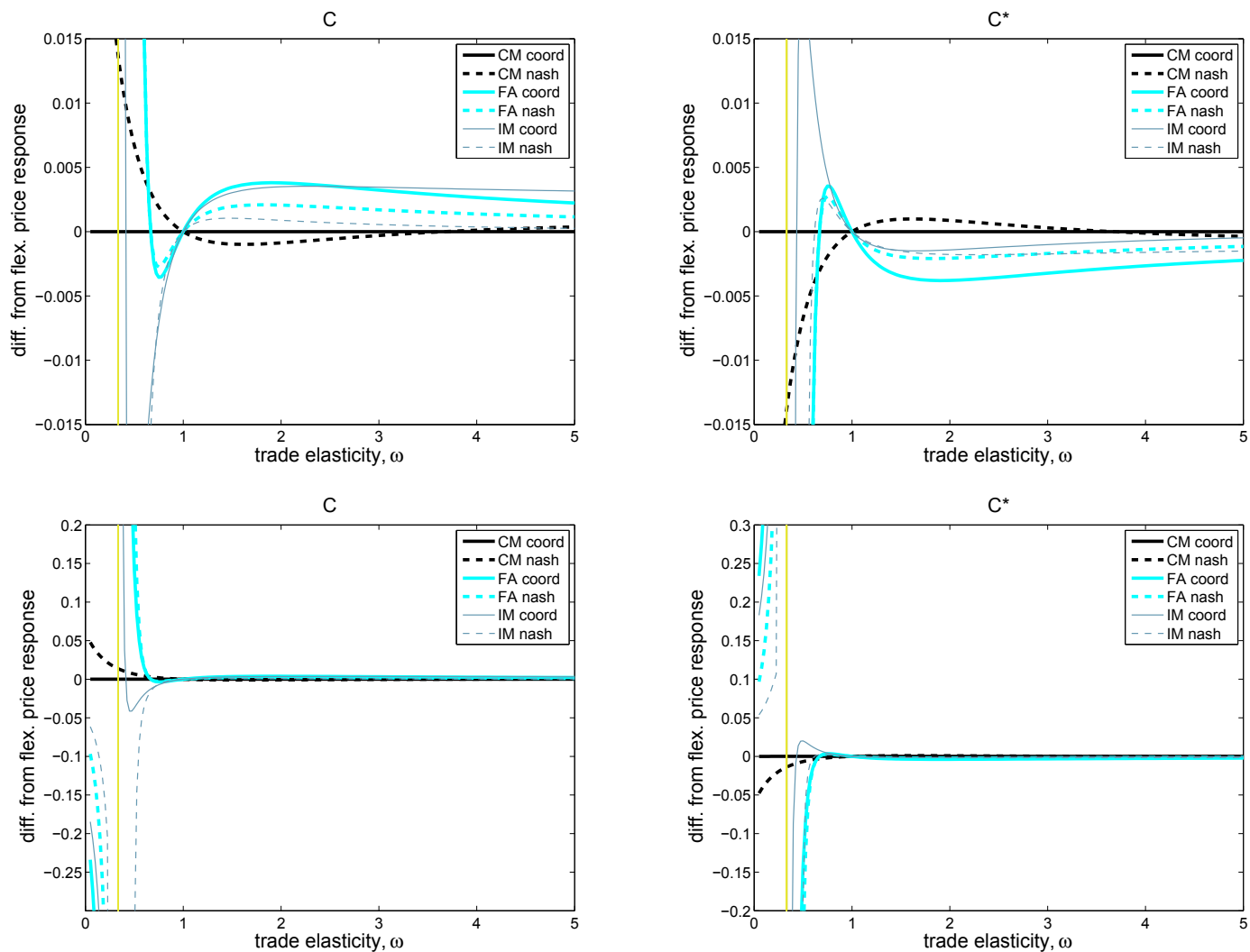

1st row: small scale on the axis of the ordinate

2nd row: same figures as row one but plotted on a larger scale 
Figure 6

Differences of optimal labor impact responses over flexible price impact responses (to a domestic $1 \%$ productivity shock), depending on the trade elasticity
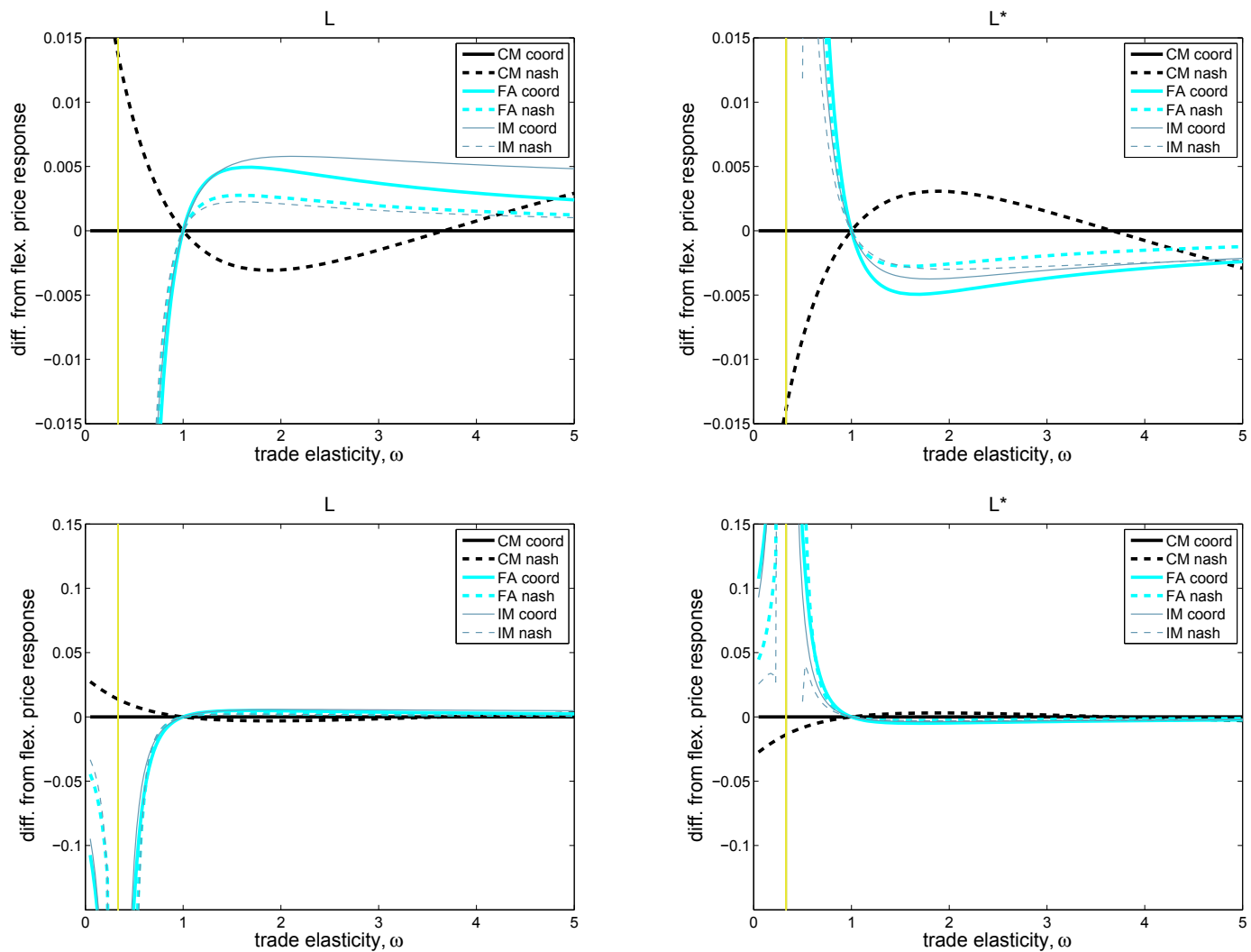

1st row: small scale on the axis of the ordinate

2nd row: same figures as row one but plotted on a larger scale 


\section{Figure 7}

Sensitivity analysis for $\sigma$ : differences of optimal labor impact responses over flexible price impact responses (to a domestic 1 $\%$ productivity shock), depending on the trade elasticity
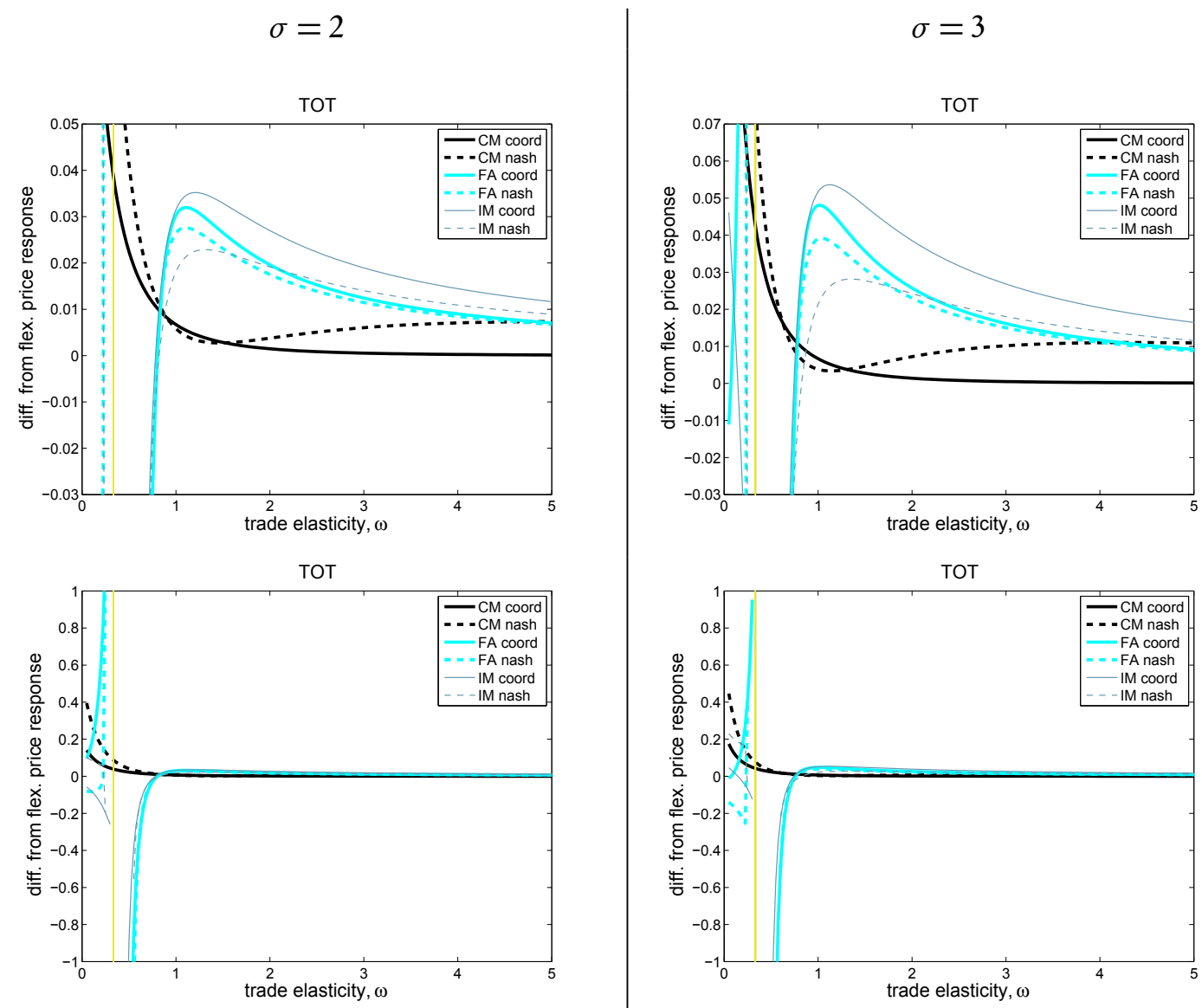

1st row: small scale on the axis of the ordinate

2nd row: same figures as row one but plotted on a larger scale 


\section{Figure 8}

Sensitivity analysis for $\gamma$ : differences of optimal labor impact responses over flexible price impact responses (to a domestic 1 $\%$ productivity shock), depending on the trade elasticity
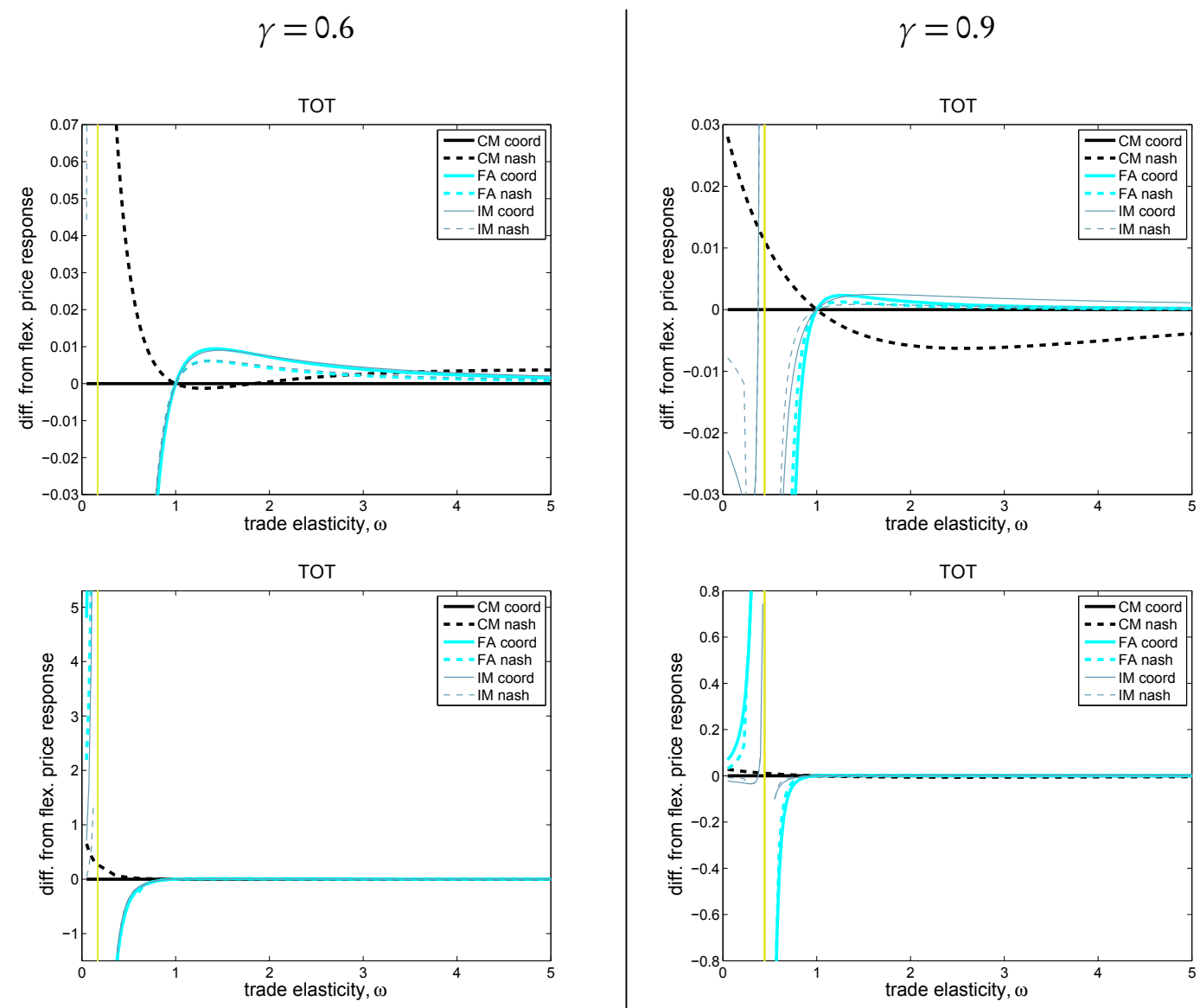

1st row: small scale on the axis of the ordinate

2nd row: same figures as row one but plotted on a larger scale 
MNB Working Papers 2010/5

The role of financial market structure and the trade elasticity for monetary policy in open economies

Print: D-Plus

H-1037 Budapest, Csillaghegyi út 19-21. 
and

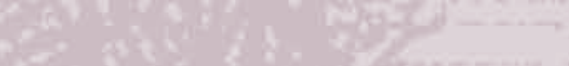

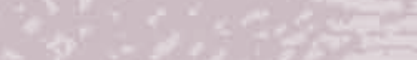

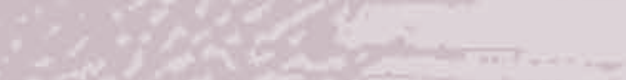

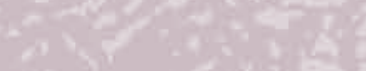

$1+2(-2.20)$

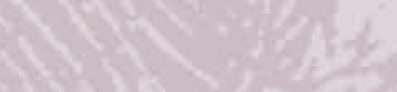
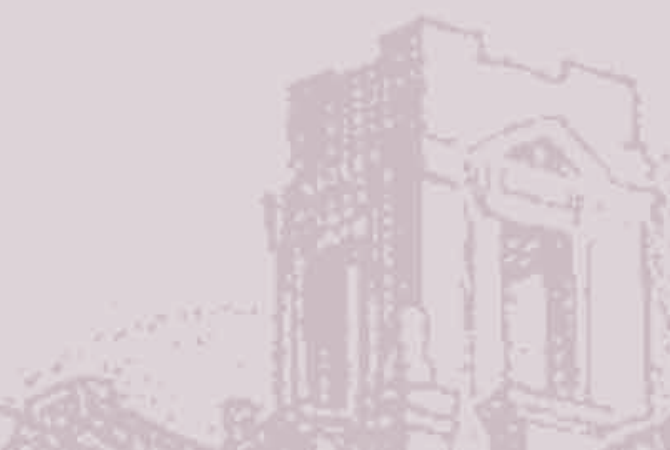

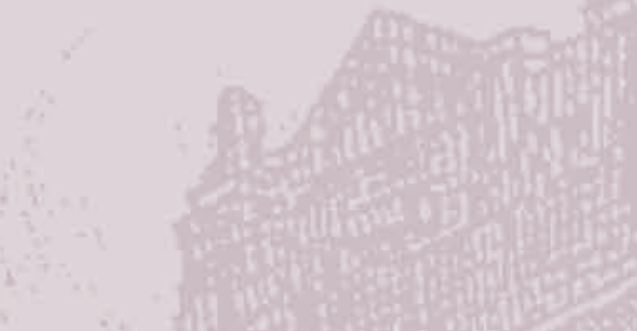

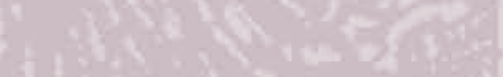
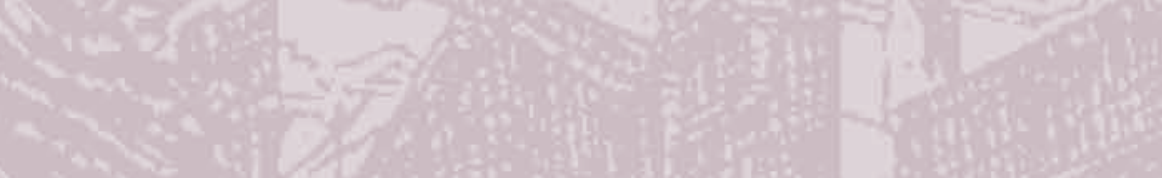

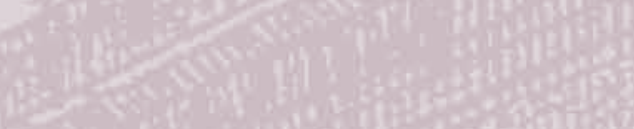

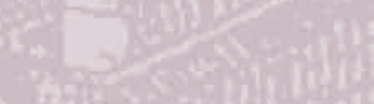
(1)

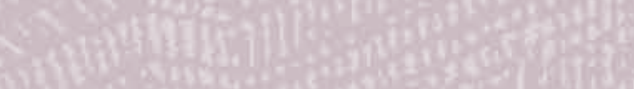

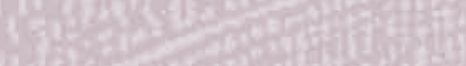

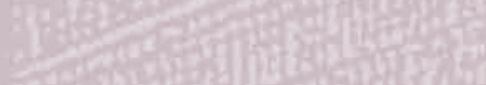
36- 